\title{
LA TABERNA. UN ESPACIO MULTIFUNCIONAL DE SOCIABILIDAD POPULAR EN \\ LA RESTAURACIÓN ESPAÑOLA
}

\author{
por \\ JORGE URÍA \\ Universidad de Oviedo
}

RESUMEN: Cargada con todos los vicios —violencia, criminalidad, prostitución-, la taberna aparece como una amenaza para el orden moral y la organización social, pero también, desde el punto de vista de los obreros militantes, como una alienación del individuo. Pero la taberna era algo más que el antro de perversión denunciada por patronos, bigienistas, moralistas, anarquistas y socialistas. Era también el espacio multifuncional de una intensa sociabilidad popular que los bistoriadores empiezan a analizar dentro de las formas populares de ocio: tertulias y reuniones políticas, juegos de cartas, canciones, bailes...

Palabras clave: Alcoholismo. Taberna. Ocio. Sociabilidad. España. Siglos XIX y XX.

ABSTRACT: Associated with all manner of vices - violence, criminality, prostitution- the tavern appears as a menace to the moral order and to social organisation, and also (from the point of view of militant workers) as an alienation of the individual. $B$ But the tavern was more than the den of corruption denounced by employers, specialists in hygiene, moralists, anarchists and socialists. It was also a multifunctional space of intense sociability wbich bistorians are beginning to analyse within the framework of popular leisure activities: "tertulias» (conversation groups), political reunions, card games, songs and dances...

KEY WORDS: Alcoholism. Tavern. Leisure. Sociability. Spain. Nineteenth century. Twentieth century.

A pocos lugares podría aplicárseles con mayor propiedad el calificativo de espacio de sociabilidad como a la taberna; de hecho, las características de voluntariedad, de «naturalidad» no interferida por otras instancias sociales —se está 
hablando de sociabilidad popular - coinciden en ser algunas de las características más notorias de la taberna ${ }^{1}$; como tienden a serlo, por lo demás, los espacios que el historiador francés Maurice Agulhon denomina de sociabilidad informal, y que han empezado a ser analizados en el caso español, y más particularmente en Asturias².

La coincidencia de rasgos como la voluntariedad o no interferencia en estas pulsiones profundas del comportamiento social, en cambio, empiezan a ser sensiblemente más matizables en el caso de la sociabilidad formal; en donde, por ejemplo, sociedades como las corales o las de socorros mutuos, están sometidas frecuentemente a una apreciable presión e injerencia de las clases dirigentes, alterándose tanto su carácter popular originario, cuanto sus propias características de formalización de impulsos asociativos profundos de carácter espontáneo o «natural». Ahora bien si el hincapié hecho en la categoría de sociabilidad sirve para subrayar la capacidad de resistencia en la taberna en lo que a las tendencias espontáneas a la asociación y a la formación de grupos de mayor o menor complejidad se refiere, libres en primera instancia de interferencias ajenas, nos es forzoso admitir que ni siquiera en el caso de un espacio de tal vitalidad, la sociabilidad popular se ve libre de los intentos del poder o de las clases hegemónicas por interferir en los aspectos más problemáticos de los comportamientos populares frente al orden establecido.

El vigor de los ataques a la taberna no sólo se explicaba por los peligros objetivos que acarreaba la ingestión de bebidas alcohólicas, sino que también se derivaba de la recelosa actitud de las clases dominantes hacia un lugar que ocupaba un puesto esencial en la sociabilidad obrera que era singularmente

1 Recuerdese la definición de sociabilidad como «sistemas de relaciones que enfrentan a los indivicuos entre ellos o les reúnen en grupos más o menos naturales, más o menos coactivos», tomada de AGULHON (en Les associations au village, Actes Sud, 1981), y difundida en España tempranamente de la mano de MAURICE, J. («Propuestas para una historia de la sociabilidad en la España contemporánea», Estudios de Historia Social, 50-51, p. 153).

2 GUEREÑA, Jean-Louis: «Una aproximación a la sociabilidad popular: el caso de Asturias bajo la Restauración (1875-1900)», Estudios de Historia Social, Madrid, n 50-51, Julio-Diciembre de 1989, pp. 214-216 y 219; SERRANO, Carlos: «Le vin du prolétaire. Alcool et sociabilité ouvrière en Espagne à la fin du XIX ${ }^{e}$ siècle», en CARRASCO, Raphaël (Ed.): Solidarités et sociabilités en Espagne (XVI $-X X^{e}$ siècles), Besançon, Annales Littéraires de l'Université de Besançon, 1991, pp. 371-389; RAMOs SANTANA, Alberto: «La sociabilidad y el vino: las tabernas», en Solera. Exposición sobre los vinos de nuestra tierra, Cádiz, Consejería de Cultura y Medio Ambiente de la Junta de Andalucía para Cultural y MundoVela, 1992; LuENGo TEIXIDOR, Félix: «De la taberna a la sociedad popular: Ocio y sociabilidad donostiarra en la primera mitad del siglo XIX (1813-1863)», en CASTELLS, Luis (Ed.): El Rumor de lo Cotidiano. Estudios sobre el País Vasco Contemporáneo, Bilbao, Servicio Editorial de la Universidad del País Vasco, 1999, pp. 55-76; URÍA, Jorge: «La taberna en Asturias a principios del siglo XX. Notas para su estudio», Historia Contemporánea, Bilbao, $\mathrm{n}^{\circ}$ 5, 1991, pp. 53-72, y «Ocio, espacios de sociabilidad y estrategias de control social: la taberna en Asturias en el primer tercio del siglo XX», en REDERO, Manuel (Ed.): Sindicalismo y Movimientos Sociales (Siglos XIX-XX), Madrid, UGT. Centro de Estudios Históricos, 1994, pp. 73-98. Como es lógico, las reflexiones del autor de estas páginas deben mucho a lo ya esbozado con anterioridad en los dos artículos que acaban de citarse.

Hispania, LXIII/2, núm. 214 (2003) 571-604 
difícil de mediatizar o coartarlo de algún modo. Es así como en Zaragoza, las autoridades provinciales pretendían en 1845 cerrar por la noche tabernas «y otros establecimientos, en donde muchos de los que concurren olvidándose de las obligaciones que tienen para con sus familias juegan y gastan lo que necesitan para las necesidades de las mismas, consagrando también al vicio un tiempo que podían emplear en procurarse medios de mejorar su situación en vez de adquirir la relajación que les conduce insensiblemente a la miseria» ${ }^{3}$.

Con frecuencia la taberna venía asociada en los discursos oficiales o moralizadores a otros espacios de sociabilidad como los cafés cantantes o las casas de prostitución, especialmente en los enclaves mineros, como en el caso de Linares (Jaén):

«Los vicios más comunes del minero son la embriaguez, el juego y la prostitución, sobre todo entre aquellos que viven ausentes de sus familias y no habiendo más distracción que la taberna, el café cantante y la casa de prostitución [....].

Estas costumbres viciosas aumentan de día en día considerablemente, pero puede decirse son tradicionales» ${ }^{4}$.

Frecuentar la taberna era, pues, una práctica masculina habitual, en particular en los grandes centros mineros e industriales donde faltaban otro tipo de distracciones:

«Los centros de ilustración que elevarían su inteligencia, están fuera de su alcance; ninguna expansión honesta le es ofrecida, ningún recreo se le facilita: la taberna, siempre la taberna, se alza en este desiertoms.

La importancia de la taberna como núcleo esencial de socialización en la vida cotidiana de las capas populares explica, en todo caso, que el suyo sea un espacio plenamente incorporado al análisis de las prácticas sociales obreras y populares; aunque, como es lógico, la perspectiva historiográfica de la sociabi-

3 Circular del Gobernador Civil de Zaragoza del 21 de junio de 1845, citada por GuereÑA, Jean-Louis: «Los orígenes del reglamentarismo en España. La policía sanitaria de las mujeres públicas (Zaragoza, 1845)», Bulletin d'Histoire Contemporaine de l'Espagne, Aix-en-Provence, $\mathrm{n}^{\circ} 25$, Junio de 1997 [Prostitución y sociedad en España. Siglos XIX y XX], p. 49.

4 NARANJo DE LA GARZA, Enrique: «Informe del Ingeniero Jefe de las Minas de Linares» (13 de junio de 1886), en Reformas Sociales. Tomo $V$. Información oral y escrita practicada en virtud de la Real Orden de 5 de diciembre de 1883. Provincias de Coruña, Jaén, Navarra, Oviedo, Palencia y Vizcaya. Publicación oficial, Madrid, Imprenta de la Viuda de M. Minuesa de los Ríos, 1893, p. 165. Ver LÓPEZ VILLAREJO, Francisco: «Prostitución y clases sociales en un núcleo minero de la Andalucía del siglo XIX», Bulletin d'Histoire Contemporaine de lEspagne, Aix-en-Provence, $\mathrm{n}^{\circ}$ 25, Junio de 1997 [Prostitución y sociedad en España. Siglos XIX y XX], pp. 103-118, y sobre el caso de La Unión (Murcia), SALAÜN, Serge: «El cuerpo del minero. Prostitución y sexualidad en La Unión», Historiar, Barcelona, $\mathrm{n}^{\circ}$ 2, Julio de 1999 [Dossier La prostitución en la España contemporánea], pp. 35-51.

5 Gimeno y AzCÁrATE, Manuel: La criminalidad en Asturias. Estadística. (1883-1897), Oviedo, Escuela Tipográfica del Hospicio, 1900, p. 56. Ver también BuYlla, A.: Cartilla de aborro social. El alcobolismo y la tuberculosis, Gijón, La Comercial, 1902, pp. 26-27.

Hispania, LXIII/2, núm. 214 (2003) 571-604 
lidad sea tan sólo una más entre las muchas posibilidades en las que cabe aproximarse a su realidad multifacética ${ }^{6}$. No hay por qué negar, en todo caso, que esta noción ha resultado particularmente fructífera para desentrañar su lógica profunda; de hecho, si la taberna no generó más estudios desde ese punto de partida, hay que achacarlo tan sólo a que la praxis de la investigación histórica española tendió claramente a privilegiar el estudio de las manifestaciones de la sociabilidad formal, en detrimento de sus vertientes informales. De no haber sucedido así, se habría estimulado sin duda la atención de los historiadores hacia las complejas funciones de las tabernas dentro del universo social de las clases populares.

El explicar las razones por las que esto ha tenido lugar derivaría estas páginas hacia una discusión historiográfica que, por lo demás, ya ha sido abordada en otro lugar. No se debió ello, desde luego, al desconocimiento en España de una matriz teórica de la sociabilidad que hacía de sus aspectos informales una de sus características más diáfanas; por el contrario, la obra de los definidores más claros del término en un plano sociológico - Durkheim, pero sobre todo Simmel y Gurvitch - fue conocida muy tempranamente en España mediante traducciones o recensiones de literatura sociológica, en donde autores como Posada mostraban estar bien al tanto de las novedades en este terreno. La aclimatación del término a la historiografía, sin embargo, tuvo dificultades añadidas; a la tradicional actitud vigilante de los historiadores ante la incorporación de conceptos provenientes de otras ciencias sociales, se sumó la aclimatación en España de una historiografía de la sociabilidad francesa cuya escasa afición a las discusiones metodológicas había sido reconocida por sus más destacados ponentes, y entre ellos el propio Agulhon. No hay duda de que ello pesó en la propensión mostrada inicialmente por los historiadores españoles a identificar las manifestaciones de la sociabilidad únicamente con sus vertientes formales - $\mathrm{u}$ organizadas como diría Gurvitch-, e incluso con el propio término de asociacionismo. Si a ello se suma la comodidad que suponía para el tratamiento de los aspectos formales de la sociabilidad, acudiendo a fuentes abarcables y accesibles, como los registros de asociaciones existentes en los Archivos centrales o los de los Gobiernos civiles, sin duda se podrá comenzar a entender un retraso en el estudio de las manifestaciones informales de la sociabilidad que sólo recientemente se ha comenzado a paliar ${ }^{7}$.

6 Véase el magnífico trabajo de SIERRA, J.: ««Rough characters». Mineros, alcohol y violencia en el Linares de finales del siglo XIX", Historia Social, n² 2 , primavera-verano 1994.

7 Estos aspectos han sido tratados por el autor de este trabajo en su colaboración sobre «Sociabilidad informal y semiótica de los espacios", en Política y Sociabilidad. En torno a Maurice Agulbon (e. p.), correspondiente al Coloquio organizado en homenaje a Maurice Agulhon por la Casa de Velázquez en febrero de 2001. Sobre la confusión entre asociacionismo y sociabilidad formal vid. URÍA, J.: «En torno a las comunicaciones presentadas a: Asociacionismo», en CASTILLO, S. y ORTIZ DE ORRUÑO, J. Ma (Coords.): Estado, protesta y movimientos sociales, Bilbao, 1998, pp. 339 y ss. 
Las reflexiones que aquí van a hacerse sobre la taberna, en este sentido, aparte de reconsiderar algunos trabajos anteriores del autor, pretenden acometerse desde la óptica de unos estudios sobre las manifestaciones de la sociabilidad donde la atención a sus aspectos informales constituye, ciertamente, una de sus dimensiones fundamentales. La sociabilidad, con todo y como es obvio, no constituye la única vía analítica de un fenómeno con tantas facetas como éste; muy al contrario el espacio de la taberna, como cualquiera otro de los lugares de intensa socialización popular, requiere para su cabal comprensión de una perspectiva transdisciplinar que combine los resultados de la investigación en fuentes literarias, la perspectiva de la historia del Arte, de los estudios geográficos, de la historia del consumo o de la del ocio, o de la historia urbana, sin olvidarse del análisis sociológico o antropológico, y por supuesto de la perspectiva semiótica ${ }^{8}$.

\section{UN ESPACIO POLIFUNCIONAL}

En lo esencial, las tabernas españoles no parecen apartarse gran cosa de las tendencias generales apuntadas hasta ahora para Europa, y que coinciden en destacar la multiplicidad de funciones de la taberna. Como bien observó E. P. Thompson en La formación histórica de la clase obrera, las tabernas británicas del finales del siglo XVIII y principios del XIX, con las que uno se topa por doquier a lo largo de los tres volúmenes de su estudio, ocupaban un lugar eminente en los orígenes frecuentemente clandestinos de la organización obrera, entre otras cosas, debido a que «no era lo más probable encontrar en tales lugares a gentle$m e n$, y [a que] un forastero sería notado tan pronto entrase en un bar»?.

Aunque las razones por las que las capas populares acudían a la taberna obedecían a un conjunto de estímulos de compleja factura, las causas de la condenación burguesa de estos locales eran en cambio de una notoria simplicidad, y obedecían más que a la preocupación por los efectos de la bebida, a la conocida asociación de la taberna con actividades de una cultura y un universo asociativo de las capas obreras con escasas posibilidades de ser interferidas allí por las capas dirigentes. Con todo, algunos de los motivos por los que se acudía a la taberna sensibilizaban aún más a la burguesía debido a su carácter poco conveniente para sus deseos de racionalización productiva y, por ende, de conformación de un obrero dócil y resignado a unos niveles salariales bajos. Era desde esa dimensión como podía comprenderse la preocupación ante el espec-

8. Sobre estas cuestiones véase el trabajo antes citado, e incluído en el volúmen homenaje a $\mathbf{M}$. Agulhon. Una perspectiva interesante del análisis socioantropológico de este tipo de locales públicos en LAURIER, E; WHYTE, A; BUCKNER, K; : «An etnography of a neighbourhood café: Informality, table arrangements and background noise»; Journal of Mundane Behavior, $\mathrm{n}^{\circ} 2,2001$.

9 ThOmpson, E. P.: La formación bistórica de la clase obrera. Inglaterra: 1780-1832, Barcelona, Laia, 1977; t. III, pp. 95-96.

Hispania, LXIII/2, núm. 214 (2003) 571-604 
táculo ofrecido por una clase obrera inglesa que se había recluido inicialmente en las tabernas para desenvolver sus sociedades secretas, sus trade unions, o sus sociedades de socorros o cooperativas en vista de los problemas para alquilar o adquirir locales de reunión ordinariamente caros o, simplemente, de las consecuencias de ordenamientos que, como la proclama real de 1839 , limitaban el derecho de reunión pública de los obreros británicos en calles y plazas.

La taberna, en realidad, era un lugar al que se acudía no sólo para beber, aunque así preferían imaginárselo unas clases altas británicas que solían contemplar a los sectores populares como un colectivo social entregado al vicio, a la incontinencia, e incapaz de morigerarse y ahorrar para mejorar una condición social de la que parecían ser los únicos responsables. El omnipresente pub, en realidad, era escenario de muchas otras actividades que caracterizaban al ocio popular británico. Era el espacio al que se recurría frecuentemente para la organización de bailes donde la juventud podía entregarse al galanteo, y el lugar preferido de entretenimiento donde se podían observar espectáculos de cantos o bailes inicialmente de carácter semiprofesional, pero germen no pocas veces del music-ball; el lugar para las discusiones o debates; en fin, las cooperativas, las sociedades de socorros mutuos o incluso las sociedades clandestinas encontraban también acomodo en sus locales. La taberna era, pues, a lo largo del siglo. XIX uno de los centros neurálgicos de la cultura popular de los trabajadores británicos y, antes de los embates sufridos desde mediados de siglo y de la adecuación de otros espacios alternativos de ocio, puede decirse que gozó de un virtual monopolio como lugar de encuentro y de relación para los trabajadores $^{10}$. Para autores como R. W. Malcolmson, sin duda entre los mejores conocedores del asunto, la taberna era en la Inglaterra del tránsito del XVIII al XIX un indispensable punto de encuentro y, sin disputa, uno de los grandes centros sociales de la comunidad junto con el mercado, o el campo comunal del pueblo o de la iglesia; era el lugar indispensable, en suma, para refrescarse y conversar a la vez que para una indispensable convivencia que había hecho de la taberna uno de los más importantes centros de intercambio y diseminación de noticias. Se explica, pues, que como hace notar Malcolmson, la taberna atrajese muy pronto la vigilante atención de los reformadores de las costumbres; que desde mediados del XVIII sometieron a un renovado ataque a todo el sistema de actividades recreativas británicas que tenían en la taberna un templo, $\mathrm{y}$ en las bebidas alcohólicas uno de sus soportes indispensables ${ }^{11}$.

10 Evans, Eric J.: The forging of the modern state. Early industrial Britain 1783-1870, New York, Longman Inc., 1983, p. 313; THOMPSON, F. M. L.: «Social control in Victorian Britain», Economic History Review, 1981, $\mathrm{n}^{\circ}$ 2, pp. 202-203; MCClellaND, Keith: "Time to work, time to live: some aspects of work and the reformation of class in Britain, 1850-1880», en JOICE, Patrick (Ed.): The bistorical meanings of work, Cambridge, University of Cambridge Press, 1989, p. 207.

11 Malcolmson, R. W.: Popular Recreations in English Society 1700-1850, Cambridge, Cambridge University Press, 1973. Las pp. 71 y ss. se dedican a la taberna; una de los capítulos ya clásicos del estudio de Malcolmson es el dedicado, a partir de la p. 118 («Popular recreations under 
Como en el caso británico, también en Francia la taberna aglutinaba una notable polifuncionalidad social. Dicho local era, en efecto, durante algún tiempo el único lugar permitido de reunión o de discusión; espacio lúdico de diversión, de cantos o de difusión de la literatura popular; refugio de las frustraciones familiares localizadas en una vivienda hostil; punto de parada en un breve intermedio del trabajo o en el camino hacia el taller o de vuelta a casa. Era también el lugar de confluencia del rumor o donde se centralizaban las noticias de un nuevo trabajo. Incluso en el caso de los ventorrillos, en las afueras de las ciudades, con un precio del alcohol más bajo por no superarse la barrera de los fielatos y con amplios espacios al aire libre, se trataba de una alternativa para un ocio familiar dominical que contradecía la imagen cotidiana del bebedor solitario y dilapidador egoísta del patrimonio familiar ${ }^{12}$.

Nada tiene de extraño, por consiguiente, que también en el caso francés los peligros del alcoholismo y la perversión de la taberna atrajesen la atención de los moralistas. De suyo, la expansión de los cafés populares como lugar de sociabilidad en el París del Segundo Imperio, está relacionada sin duda con la difusión de la creencia, sustentada por los publicistas e higienistas de la época, en las virtudes de una bebida que a estas alturas ha dejado ya de ser exótica, y que es contemplada como antídoto fisiológico y social del alcohol; asumiendo así funciones similares a las que el té había tenido para los reformadores morales británicos. La epidemia alcohólica se convierte en origen de múltiples males, y la Academia de Medicina francesa discute en serio en los años setenta la influencia del alcoholismo en la derrota de 1870 , y en los sucesos de la Comuna de $1871^{13}$.

En realidad la definición de este tipo de preocupaciones en torno a la taberna formaba parte de un proceso mucho más general, que afectaba además de a los países citados a todo el occidente industrializado, y que había acompañado al paralelo auge del consumo en los alcoholes y el incremento de las tabernas; sería sin embargo en el ámbito anglosajón, como es bien sabido, y en concreto en los Estados Unidos y en Gran Bretaña, donde se definiría más tempranamente y con mayor claridad este discurso alarmista sobre los efectos sociales del alcohol y las tabernas. En realidad desde el siglo XVIII se estaban produciendo cambios importantes en las formas de beber entre las clases popu-

attack»), a las campañas de moralización de las costumbres y, por supuesto, a los ataques hacia el alcohol y la taberna.

12 AGUlHON, Maurice: "Working class and sociability in France before 1848», en THANE, Pat, CROssick, Geoffrey y Floud, Roderick (Eds.): The power of the past. Essays for Eric Hobsbawm, Cambridge, Cambridge University Press, 1984, pp. 37-66; BrennAN, Thomas: Public Drinking and Popular Culture in Eighteenth Century Paris, Princeton, Princeton University Press, 1988.

13 CSERGO, J.: «Extension et mutation de loisir citadin, Paris XIXé siècle - début Xxé siècle», en Corvin, A., L'Avènement des Loisirs 1850-1960, Paris, Aubier, 1995, p. 137. Bergeron, J.: «Rapport sur la répression de l'alcoolisme, fait devant l'Academie de médecine, le 5 décembre de 1871 ", Bulletin de l'Académie de Médecine, XXXVI, p. 993; citado en LÉONARD, J., La France médicale au XIXé siècle, Paris, Gallimard, 1978, pp. 191-192. 
lares favorecidos por el incremento del poder de compra de las capas obreras; por la puesta a punto de métodos de obtención de alcoholes más industrializados, masivos y baratos; por la facilitad y economía de los transportes, o por los procesos de mayor producción agrícola que favorecieron la conversión de los excedentes en alcoholes, de más fácil almacenamiento, conservación y venta ${ }^{14}$. Nada de particular tiene, por tanto, que nos encontremos en España con un local intensamente vinculado al ocio popular, aspecto en el que la taberna resultaba ser, también aquí, un punto de referencia indispensable ${ }^{15}$. Las tabernas -y muy especialmente las sidrerías y lagares abiertos al público en el caso asturiano- volvían a aparecer como locales asociados al canto de coplas y de tonadas típicas del país; y tabernero hubo que echó el resto para contratar a afamados gaiteros como el de Libardón, toda una celebridad popular a principios del siglo $\mathrm{XX}^{16}$.

Bastaba, por lo demás, que se abriese un patio de vecindad en los aledaños de la taberna, o que ésta se ubicase en las afueras de la ciudad, para que se dispusiese del espacio bastante para poder desarrollar juegos al aire libre, sobre todo los bolos. Ese espacio anejo al local de la taberna, especialmente en el caso de que ésta se localizase en las afueras, solía tener un emparrado de plátanos de Indias a cuyo cobijo se ubicaban unas cuantas mesas o bancos para el acomodo de los usuarios, que solían ser bastantes en domingo, y que aumentaron su presencia cuando los tranvías facilitaron la salida del centro de las ciudades ${ }^{17}$. Además de este último tipo de local, el merendero, las funciones propias de la taberna podían presentarse asociadas a otras, aunque lo esencial de su papel seguía siendo la venta de bebidas a bajo precio. En ese caso estaban algunas tiendas mixtas, especialmente en zonas rurales; los figones o casas de comidas, que en lo esencial debían de seguir siendo tabernas la mayor parte del día; en fin, ninguna diferencia ostensible había entre el chigre - nombre de la taberna en Asturias- y el café económico, paraguas protector tras el cual podía esconderse un local que el tabernero pretendía proteger de la vigilancia y las restricciones legislativas de las autoridades.

El florecimiento de las tabernas, de todos modos, y como es bien obvio, no es una peculiaridad del norte de España; bien al contrario, en lugares como Madrid, el peso del sector en la estructura general de los establecimientos comerciales es abrumador en barrios como el de la Latina en 1903. Entre 1900 y los años veinte, de hecho, el ramo de los establecimientos de bebidas ocupan invariablemente el segundo puesto por volumen de contribuyentes en la estructura comercial de la capital española, inmediatamente detrás del sector de

14 Campos Marín, R: Alcobolismo, medicina y sociedad en España (1876-1923), Madrid, CSIC, 1997, pp. 26-27.

15 URÍA, Jorge: «La taberna en Asturias a principios del siglo XX», op. cit., pp. 54-56; LUENGO TeIXIDOR Félix: «De la taberna a la sociedad popular», op. cit., pp. 63-67.

16 ARrones PeÓn, Luis: Hostelería del viejo Oviedo, Oviedo, s.ed., 1974.

17 Alvar GonzÁlez, Ramón María: Los tranvías de Gijón, Gijón, Cía. de Tranvías, 1990. 
la alimentación; y su participación total en el conjunto de los establecimientos comerciales madrileños oscila entre el $23,4 \%$ de 1900 y el $17,6 \%$ de 1925 $26^{18}$. También las tabernas asturianas eran motivo de preocupación de las autoridades. En aquellos lugares, el proletariado podía entregarse con bastantes menos cortapisas a lo que se entendían como conductas viciosas o depravadas. Era aquel uno de los pocos locales de uso colectivo y a cubierto en donde se podía blasfemar a plena libertad en un momento en que la Iglesia y el Gobierno Civil habían desatado sonoras campañas contra la blasfemia; que si hay que pensar que nunca consiguieron amenazar seriamente hábito tan arraigado en la región, no dejaban de molestarlo un tanto ${ }^{19}$. Además de consumirse bebidas alcohólicas, sobre sus mesas o en habitaciones interiores reservadas, se jugaba a los naipes, otro de los vicios responsables, según la literatura del momento, de la desaparición de buena parte de los jornales y de la ruina de la familia. La taberna, finalmente, no era ajena en absoluto a la celebración de mítines y actos políticos, al desarrollo de discusiones colectivas que también podían tener contenido político, o a la presencia de tertulias ácratas o socialistas ${ }^{20}$.

Pero si este conjunto de actividades que tenían como marco la taberna y que tanto preocupaban a las capas dirigentes, podían tener un poder de atracción cierto sobre la clase obrera, no puede obviarse el hecho de que en realidad, y pese a su importancia, no eran sino funciones en cierto modo adjetivas del local. Lo esencial de la taberna, lo que la definía en última instancia, era la apetencia popular por las bebidas alcohólicas; lo que necesariamente tiene que llevarnos a plantear las razones de este arraigado hábito.

\section{ALCOHOL Y VIDA COTIDIANA}

Aunque los moralistas británicos lamentasen que el proletariado preferiese las propiedades saciantes de la cerveza antes que las del té, la bebida típicamente propugnada por las ligas de templanza británicas, lo cierto fue que las tabernas siguieron siendo frecuentadas y que a ellas se continuó acudiendo, entre otras muchas cosas, para apagar simplemente la sed. El alcohol, por lo demás, podía funcionar como un alimento, y con frecuencia constituía un apor-

18 Nielfa CRISTÓbal, G.,: Los sectores mercantiles en Madrid en el primer tercio del siglo XX, Madrid, Ministerio de Trabajo y Seguridad Social, 1985, pp. 65, 84 y 268-311.

19 URíA, Jorge: «La enseñanza del catecismo en Asturias a principios del siglo XX», en AYMES, Jean-René, FELL, Ėve-Marie y GuEREÑA, Jean-Louis (Eds.): École et Eglise en Espagne et en Amérique Latine. Aspectos idéologiques et institutionnels, Tours, Publications de l'Université de Tours (Études Hispaniques, $\mathrm{n}^{\circ}$ VIII-IX), 1988, pp. 61-88.

20 Del Rosal, Amaro: «La taberna como centro de discusión política en Asturias (19141920)", Los Cuadernos del Norte, Oviedo, III, n 14, Julio-Agosto de 1982, pp. 79-84; GoNZÁLEZ TrOYANO, Alberto: «De las tertulias ilustradas a las tabernas románticas», en Los espacios de sociabilidad sevillana, Sevilla, Fundación El Monte, 1997, pp. 9-33. 
te calórico indispensable en dietas usualmente carenciales. Los poderes nutritivos del alcohol fueron de todos modos objeto de discusión entre los medios antialcohólicos españoles; el asunto se planteaba a propósito de la distinción entre las bebidas alcohólicas de fermentación natural, como el vino y la cerveza, acerca de las cuales tanto en Francia como en España existía una corriente favorable a su uso, y los destilados, cuya mayor toxicidad había suscitado una corriente de opinión contraria. A la discusión se sumaron, además, ingredientes no estrictamente bromatológicos o médicos. Desde los años ochenta del siglo XIX numerosos sectores ligados en España a la producción vitivinícola secundaban también estas críticas tras la firma de un tratado con Alemania, de 1883 y ratificado en 1887, que permitía la importación de alcoholes industriales de aquella procedencia a bajos precios. La medida posicionó en su contra rápidamente a los productores de buenos vinos españoles, argumentando que atacaban las destilerías nacionales y favorecían la producción de vinos artificiales encabezados con alcohol alemán, mientras que a su favor se levantaban los productores de Valencia y ciertas partes de Cataluña, que precisaban de los baratos alcoholes alemanes para rectificar la baja calidad de sus vinos. En la discusión se habían mezclado sectores tan heterogéneos como las Cámaras de Comercio de uno u otro lugar, el Servicio Agronómico, el Instituto Agrícola Catalán o la propia Academia de Medicina; en general los médicos se habían alineado con los intereses de los productores vitivinícolas ${ }^{21}$.

Por su traducción inmediata en energías, el consumo puntual de alcohol parece haber tenido un lugar importante, por otra parte, en los hábitos de trabajo de determinadas categorías laborales hasta traducirse en pautas de conducta perfectamente codificadas y con denominaciones lingüísticas igualmente definidas. En Francia, la «consoladora», por ejemplo, era el trago de un golpe a las cinco de la mañana para empezar el día olvidando por un instante las miserias cotidianas, la propia fatiga o el desgaste del cuerpo; y el «latigazo», a su vez, pautaba el ritmo de trabajo y de las consumiciones de los albañiles, los descargadores o los pudeladores.

Puesto que por sus efectos depresores sobre la corteza cerebral el alcohol era un tradicional desinhibidor al tiempo que un estimulador de los sentimientos de euforia y bienestar, nada más lógico que funcionase - y así venía haciéndolo desde hacía siglos - como un procedimiento compensador de otras frustraciones cotidianas. El alcohol pasaba a ser así refugio ante la explotación y alienación cotidianas en el centro de trabajo, pero también se erigía en alternativa frente a las frustraciones de una familia trabajadora en la miseria y cuajada de fracasos y desgracias. La taberna se convertía así en un medio de aislarse de un hogar infeliz y que, además, solía reunir escasas condiciones de habitabilidad. De hecho, y aunque no faltasen casos de mujeres bebedoras, y el

21 Pan Montojo, J.: La bodega del mundo. La vid y el vino en España (1800-1936), Madrid, 1994, pp. 212-229. CAMPOS MARÍN, R.: Alcobolismo, medicina..., opus cit., p. 127-144.

Hispania, LXIII/2, núm. 214 (2003) 571-604 
propio varón se convirtiese los domingos en un padre solícito y amante de la familia, durante el resto de la semana la taberna era habitualmente un espacio típicamente varonil y aislado del contacto de las mujeres. La propia bebida y su ritualización tenía ingredientes asociados a la virilidad y al fortalecimiento del compañerismo entre los varones trabajadores; la bebida en común, o la ronda, saludaban no sólo la solidaridad interna entre los trabajadores de una misma cuadrilla o turno, sino también cualquier acontecimiento venturoso, como el día de paga, el encuentro con un amigo, etc. ${ }^{22}$.

La ingestión de alcohol en la taberna, por tanto, tenía un papel insoslayable en la vida asociativa cotidiana de los trabajadores; y en realidad no hubo durante algún tiempo alternativa a este local. A mediados de siglo, en Francia, ni siquiera era posible o usual adquirir el vino para consumirlo privadamente en el domicilio, sino que había que recurrir necesariamente a la taberna, único punto de venta existente del género, para degustarlo. Como en Inglaterra, la iglesia no era un competidor serio de las tascas a la hora de jerarquizar el ocio, y en cuanto a otro tipo de alternativas, como los espectáculos teatrales, ni siquiera le eran comprensibles buena parte de las veces al trabajador del común. Por otra parte, durante algún tiempo la ausencia de jardines, plazas o paseos dentro del casco de la ciudad, también acababan por echar de bruces al proletariado en dirección a la taberna. Sin ir tan lejos, a principios del siglo XX, las ciudades españolas seguían siendo espacios poco menos que monopolizados en su uso por la burguesía; la arquitectura, los edificios públicos, las características y los precios de los espectáculos en gran medida se determinaban en función suya, y el proletariado tuvo que librar una constante lucha por conquistar nuevos espacios para el ocio, e incluso protagonizar verdaderas batallas con la policía para poder acceder al disfrute de cosas tan elementales como los conciertos de banda en los paseos más elegantes. La taberna seguía siendo en estas condiciones el lugar de relación más accesible; no había que pagar cuota alguna para entrar en sus locales, el vino seguía siendo barato, y el horario de apertura se adaptaba plenamente al tiempo de que disponía el trabajador: escaso y de provisión irregular ${ }^{23}$.

El papel de la taberna como núcleo social, espacio de socialización multifuncional, o lugar insustituible para el ocio, fue percibido por lo demás con

22 Evans, Eric J.: The forging of the modern state, op. cit., p. 313; CORBIN, Alain, GUERRAND, Roger-Henri y PERROT, Michelle (Eds.): Sociedad burguesa: aspectos concretos de la vida privada, vol. 8 de ArIÈs, Philippe y DuBY, Georges (Eds.): Historia de la vida privada, Madrid, Taurus, 2001, pp. 284-285; AGULHON, Maurice: "Working class and sociability», op. cit., pp. 42-43. La taberna, descrita como espacio típicamente masculino en las tascas jerezanas, aparece también en RAMOS SANTANA, Alberto: «La sociabilidad y el vino: las tabernas», op. cit., p. 30.

23 AgulHon, Maurice: "Working class and sociability", op. cit., pp. 42-43; MCClelland, Keith: "Time to work, time to live», op. cit., p. 20; RULE, John: Clase obrera e industrialización. Historia social de la revolución industrial británica, 1750-1850, Barcelona, Ed. Crítica, p. 323; URíA, Jorge: Sociedad, ocio y cultura en Asturias (1898-1914), Tesis de doctorado, Universidad de Oviedo (edición en microfichas), 1991, t. III, pp. 813-1027. 
notoria lucidez por los contemporáneos. La fina sensibilidad social de Concepción Arenal la había visto ya, corriendo el año 1874, como un espacio a donde acudían los sectores populares buscando «sociedad y distracción (...), conversación animada", juego, o en definitiva pasar "el tiempo agradablemente» o encontrar «descanso y solaz». Es cierto que su caso era, de todos modos, el de una literata y publicista con muy conocidas, y hasta polémicas, vertientes de tratadista de temas sociales; pero el de la taberna fue en realidad un tema ampliamente tratado en la creación literaria, donde brillaba toda la formidable mezcla de prejuicios y de complejos problemas que concurrían en su espacio. Aunque sea adelantar acontecimientos, bueno será recordar una de las mejores recreaciones hechas en la época de las tabernas mineras asturianas, la de las que había conocido Doña Paula, la madre del Magistral en el formidable retrato de la sociedad de la Restauración que es La Regenta, de Leopoldo Alas Clarín. El padre de Paula, en efecto, pertenecía a la plétora de «hombres que salían de las cuevas negros, sudando carbón y con los ojos hinchados, adustos, blasfemos como demonios", y acababan gastando «en la taberna y en el juego lo que ganaba en la mina». El retrato de la taberna, y el de los mineros que la frecuentan no puede ser más hostil; la asociación entre la delincuencia y los vicios sociales y este indispensable lugar de encuentro y de solaz tras el duro trabajo, ubicado al pie mismo de la salida de la mina, se destaca aquí con toda nitidez. Su espacio es escenario de «reyertas trágicas», o de vuelos de «sillas por el aire, cuchillos que acababan por clavarse en una mesa de pino», o «amenazas sordas y reconciliaciones expresivas». Doña Paula

«[...] a la boca de una mina había levantado cuatro tablas, para instalar una taberna. [...] [...]. Los mineros la encontraban al salir a la claridad, y allí, sin dar otro paso, apagaban la sed y el hambre, y la pasión del juego que dominaba a casi todos. Detrás de unas tablas, que dejaban pasar las blasfemias y el ruido del dinero, estudiaba en las noches de invierno interminables el bijo del cura [Fermín de Pas] [...]. El espectáculo de la ignorancia, del vicio y del embrutecimiento le repugnaban hasta darle náuseas [...]. Paula padeció mucho en esta época; la ganancia era segura y muy superior a lo que pudieran pensar los que no la veían a ella explotar los brutales apetitos, ciegos y nada escogidos de aquella turba de las minas; pero su oficio tenía los peligros del domador de fieras; todos los días, todas las noches había en la taberna pendencias, brillaban las navajas, volaban por el aire los bancos. La energía de Paula se ejercitaba en calmar aquel oleaje de pasiones brutales, y con más ahínco en obligar al que rompía algo a pagarlo, y a buen precio»

Asoma en el texto, desde luego, alguno de los otros tópicos de la taberna; el del vicio de la inmoderación en el gasto de los mineros, por ejemplo, y el de la codicia de los taberneros que saben aprovecharse de ello. Al parecer, en cualquier otra industria que emprendiese doña Paula

«con sus pocos recursos, no podría ganar la décima parte de lo que iba ganando allí. Los mineros salían de la oscuridad con el bolsillo repleto, la sed y el 
hambre excitadas, pagaban bien, derrochaban y comían y bebían veneno barato en calidad de vino y manjares buenos y caros. En la taberna de Paula todo era falsificado; ella compraba lo peor de lo peor y los borrachos lo comían y bebían sin saber lo que tragaban, y los jugadores sin mirarlo siguiera, fija el alma en los naipes» 24 .

Hora habrá de volver, en todo caso, sobre todos y cada uno de estos puntos. Por el momento interesa retener el hecho, desde luego, de la ubicuidad de la taberna, de su extrema accesibilidad al pie del tajo; de su caracterización como espacio esencial, antes que el del hogar o el de la calle, a los que substituye con ventaja en la sociabilidad masculina de los trabajadores.

Nada tiene de particular, por tanto, que muchos estudiosos de las capas populares vean en la taberna un lugar central en la conformación de su modo de vida, de la cultura popular o, por mejor decirlo, de una sociabilidad popular; entendiendo por sociabilidad, como lo hace Maurice Agulhon, «la peculiar aptitud para vivir dentro de grupos y consolidar esos grupos mediante la formación de sociedades voluntarias»; impulso relacional que constituiría un «sistema de relaciones que enfrentan a los individuos entre ellos o les reúnen en grupos más o menos naturales», y que abarcaría «todo aquello que estructura la práctica social entre la familia por una parte, y los cuerpos constituídos por otra» ${ }^{25}$.

\section{El espacio interno de LA TABERNA}

El carácter refractario de la taberna hacia los intentos de control sobre las manifestaciones de la cultura popular, su distinción como lugar poco interferido ante las tentativas que pondrán en práctica tanto las capas dirigentes, cuanto los grupos obreros conscientes, como los nucleados en torno al socialismo español, es algo ya conocido y sobre lo que se ha insistido suficientemente ${ }^{26}$. No hay duda de que todo ello contribuyó a preservar su carácter de espacio de sociabilidad, y de verdadera fortaleza donde la cultura popular conseguiría resistir los embates sucesivos que iban a lograr controlar y domeñar el ocio popular en otros ámbi-

24 Clarín: La Regenta, Madrid, 1966, pp. 306-312. La cita de C. ArenAl, la hace CAMPOS MARÍN, R.: «Tabernas, sociabilidad obrera y control social en el Madrid de la Restauración», en FRAILE, P.: Modelar para gobernar. El control de la población y el territorio en Europa y Canadá. Una perspectiva histórica, Barcelona, Universitat de Barcelona, 2001.

25 Para el concepto de sociabilidad, ver GUEREÑA, Jean-Louis: «Un ensayo empírico que se convierte en un proyecto razonado: Notas sobre la historiografía de la sociabilidad", en VALÍN, Alberto (Ed.): La sociabilidad en la Historia contemporánea. Reflexiones teóricas y ejercicios de análisis, Ourense, Duen de Bux (Historia. Estudios -1), 2001, pp. 13-29.

${ }_{26}$ URÍA, J.: «La taberna...», opus cit.. DE LuIS MARTín, F; y ARIAS GONZÁlEZ, L.: Las Casas del Pueblo socialistas en España (1900-1936), Barcelona, Ariel, 1997, pp. 58-60. CAMPOS MARÍN, R.: «El obrero abstemio. Salud, moral y política en el discurso antialcohólico del socialismo español a principios de siglo», Historia Social; nº 31, 1998. 
tos. La taberna llegó a ser así el lugar de reclusión de formas particularmente tardías de ocio popular que ya habían caído en desuso en lugares públicos ${ }^{27}$.

Pero, puesto que estamos hablando de espacios de sociabilidad, bueno será interrogarnos acerca de en qué manera el territorio interno de la taberna se configuraba para favorecer activamente sus funciones relacionales o, inversamente, en qué medida la codificación de ese espacio se adaptaba o reconocía la socialización habitualmente ejercida en su interior. En uno u otro caso, para contestar a este interrogante, es preciso partir de un reconocimiento previo del hecho de que ese espacio está organizado internamente hasta responder a una codificación semiótica, a un lenguaje que es preciso descifrar y que es expresión, al tiempo que factor multiplicador, de una funcionalidad precisa ${ }^{28}$.

No es fácil llegar, de cualquier modo, a un estándar en cuanto a la configuración de la taberna aunque, por el momento, y a falta de fuentes de mayor calidad, podamos valernos de algunos testimonios literarios o pictóricos que puedan ayudar a reconstruir su espacio interno. En cuanto a la literatura, desde luego, y al margen de otros testimonios de menor valía documental, probablemente una de las descripciones más logradas de la taberna se encuentre en las acotaciones escénicas puestas a la mítica pieza de teatro de Dicenta Juan José (1895); sin duda una de las obras más representadas en los teatrillos populares de las Casas del Pueblo y los Ateneos asturianos y a la que, por tanto, hay que reconocerle un aceptable grado de sintonía con las clases populares y sus necesidades cotidianas. La descripción relativamente precisa merece citarse en totalidad:

«El teatro representa el interior de una taberna de los barrios bajos. Al fondo una puerta de cristales, de dos hojas, con cortinillas en las vidrieras. Al lado derecho de la puerta del fondo, un escaparate con fondo y puertecillas de cristal. En segundo término, a la izquierda, un mostrador de madera forrado de zinc en su parte superior y en los bordes; sobre el mostrador, empotrada en él una cubeta de zinc, de la que arranca una pequeña cañería de fuente rematada por un tubo de goma. Encima del mostrador, vasos, copas, botellas, frascos llenos de vino y una jarra con tapadera de madera. Entre el mostrador y el escaparate, una trampa practicable que da acceso a la cueva del establecimiento. A la izquierda del mostrador, entre éste y el escaparate, una puerta que comunica con la cocina.

En primer término, a la izquierda, un velador, en torno del cual, así como en el de tres o cuatro veladores que ocuparán la escena convenientemente distribuídos, se colocarán taburetes de madera.

A la derecha, una puerta de cristales con cortinillas encarnadas que da paso a una habitación reservada. Sobre la puerta de la derecha, un reloj de pared. A lo

27 Sobre el carácter de la taberna como espacio no interferido por la burguesía, ver THOMPSON, E. P.: La formación histórica de la clase obrera, op. cit., t. III, pp. 95-96, y sobre las campañas socialistas contra la taberna, URíA, Jorge: «La taberna en Asturias a principios del siglo XX», op. cit.

28 Se considerará la organización de ese espacio, por tanto, como integrada en un campo semiótico al modo como lo define ECO, Umberto, en La estructura ausente, Barcelona, Ed. Lumen, 1978.

Hispania, LXIII/2, núm. 214 (2003) 571-604 
largo de la pared de la derecha, una estantería de madera pintada, con botellas de varias clases llenas y vacías.

Cuídese mucho de todo lo referente al servicio de vino, enjuague de las copas y demás detalles que se irán marcando en el curso de la representación.

La escena, lo mismo que el escaparate y la habitación reservada, cuando de ella se haga uso, estarán alumbradas por mecheros de gas.

Al levantarse el telón, aparecen en escena cuatro bebedores jugando a las cartas en un velador de segundo término. En un taburete colocado al lado de los jugadores habrá una bandeja con varias copas de vino a medio apurar. El tabernero al lado de los jugadores, mirando el juego.

Ignacio y Perico sentados frente al velador de la izquierda. Encima de este velador habrá una botella y dos vasos. Perico tiene un periódico en la mano.

El mozo estará en pie detrás del mostrador»29.

En cuanto a los testimonios pictóricos, resultan en casos como el asturiano excepcionalmente parcos; del casi medio centenar de cuadros catalogados con temática relacionada con la manzana y la sidra, la mayoría no se adaptan a nuestros fines por su temática, difícil localización o carácter escasamente documental. Tan sólo un par de ellos reúnen características verdaderamente aprovechables: el cuadro de José Uría La Pipiona, conocido hoy a través de una fotografía, y un dibujo de Evaristo Valle de temática costumbrista reproducido en un porfolio veraniego gijonés de $1906^{30}$.

Ateniéndonos a esta documentación, puede disponerse de una idea bastante exacta del interior de una taberna tipo. De acuerdo con la descripción del Juan José, una de las primeras cosas a destacar en ella era, sin duda, la reticulación de su espacio en unidades menores y adecuadas para la formación de grupos generalmente pequeños de parroquianos en torno a mesas y taburetes; cuya fácil movilidad debido al uso de materiales ligeros por su baratura permitía, en todo caso, adaptarse con facilidad a las habituales fluctuaciones en las dimensiones de los grupos; la diferencia en este sentido con el café burgués es notoria, puesto que en sus interiores la existencia de divanes o de mesas de hierro y mármol, dificultaban algo más lo que en la taberna era una intensa maleabilidad del espacio interno ${ }^{31}$.

En torno a esas mesas, en cualquier caso, era donde se organizaban las actividades más comunes de la taberna: la bebida, pero también la lectura, la con-

29 DiCENTA, Joaquín: Juan José. Drama en tres actos y en prosa. Estrenado con extraordinario éxito en el TEATRO DE LA COMEDIA la noche del 29 de Octubre de 1895, 14ª ed., Madrid, R. Velasco, Imp., 1912, pp. 7-8.

30 Ver «La manzana y la sidra en la pintura asturiana», en El libro de la sidra, Oviedo, Pentalfa, 1991. El dibujo de Evaristo Valle se reproduce en GONZÁLEZ LAFITA, Pilar: Las artes gráficas en Gijón, 1890-1920, Gijón, Ayuntamiento de Gijón, 1984, p. 174.

31 Sobre el café, ver FERNÁNDEZ SEBASTIÁN, Javier: «Los primeros cafés en España (17581808): nueva sociabilidad urbana y lugares públicos de afrancesamiento", en AYMES, Jean-René (Ed.): L'image de la France en Espagne pendant la seconde moitié du XVIII siècle, Alicante-Paris, Instituto de Cultura «Juan Gil-Albert»-Presses de la Sorbonne Nouvelle, 1993, pp. 63-82. 
versación o el juego a los naipes; actividades todas ellas que se documentan fehacientemente en el texto de Dicenta. Los ligeros taburetes de madera pueden documentarse en muchas pinturas o grabados de la época, por ejemplo en el dibujo de Valle que se ha citado. La descripción de la taberna parisina del XVIII, por lo demás, coincide en lo esencial con la del texto de Dicenta, incluso en la forma y los detalles del mostrador o en la existencia de espacios y habitaciones privadas interiores ${ }^{32}$. La persistencia de los apartadillos o camarotes interiores, así como la importancia de los mostradores como divisoria entre el espacio público/privado de estos establecimientos se documenta por otra parte en el caso de las tabernas jerezanas 33 .

El mostrador es otro de los lugares centrales de ese espacio; lugar, tal vez, de venta de vino o alcoholes para llevar al domicilio - la taberna tiene un «escaparate» que parece aproximarlo a las prácticas y a la fisonomía del pequeño comercio- Seguramente, el mostrador actuaba también como mesa de servicio y para organizar el reparto de la bebida por las mesas - el mostrador parece estar completamente lleno de botellas y vasos-. Pero tampoco hay duda alguna de que el mostrador actuaba también de parapeto para la venta y consumición directa de vinos y licores; y si la descripción de Dicenta puede ser confusa en este punto, el dibujo de Valle despeja dudas sobre este extremo.

El detalle no deja de tener interés, puesto que marca notables diferencias con el café burgués. En 1914, el Café Imperial de Avilés no tenía barra, y la distribución de las consumiciones se hacía directamente en la mesa desde trincheros, aparadores o mesas auxiliares que centralizaban el servicio ${ }^{34}$. Hubo que esperar a los años treinta para que apareciesen las primeras barras americanas en el centro de ciudades como Oviedo ${ }^{35}$. La existencia del mostrador, por tanto, marcaba una diferencia esencial con el café burgués; en el caso de la taberna, la clientela obrera tenía que adaptarse a la disponibilidad de un ocio casi furtivo, escaso y disperso, lo que podía hacer inútil el gesto de sentarse a una mesa y, por el contrario, hacía indispensable el mostrador para tomar el «tentempié»; la burguesía o las clases medias sentadas en el café, desde luego, vivían en circunstancias muy distintas.

La necesidad de vivir apegado a ritmos de trabajo minuciosamente cronometrados otorgaba una funcionalidad muy precisa, por lo demás, al reloj de pared de la taberna de Dicenta y, todavía más, al del dibujo de Valle, tras el mostrador y frente a la vista del bebedor a pie firme. Las diferencias con el café son aquí, otra vez, demasiado obvias; si, en el caso del café, solía haber relojes, sólo en el de la taberna obrera eran artículos singularmente caros y cuya adquisición únicamente podía justificarse por una necesidad imperiosa.

\footnotetext{
32 Brennan, Thomas: Public Drinking and Popular Culture, op. cit. Para su estudio, el autor dispuso, aparte de grabados de la época, de inventarios de bienes de taberneros bastante detallados.

33 Ramos SANTANA, Alberto: "La sociabilidad y el vino», op. cit.

34 Fotografía en la revista $E l$ Bollo, Avilés, 1914.

35 ARRONES PEÓN, Luis: Hostelería del viejo Oviedo, op. cit., p. 85.
} 
Otros datos nos informan, a su vez, de detalles adicionales de la funcionalidad del espacio de la taberna: las habituales estanterías del botellero, una habitación reservada - seguramente para juegos prohibidos por la ley o para otras actividades que requiriesen la ocultación de las miradas ajenas-, así como dependencias complementarias para la mejor venta de los licores: la cueva, para refrigerar y conservar las bebidas, y la cocina para el servicio del propio tabernero y su familia y, tal vez, también para el de la clientela.

En fin, algunas informaciones del texto de Dicenta contradicen notoriamente la idea de la publicística de la época que se empeña en dibujar la taberna como un local antihigiénico. Si eso era así, seguramente no se debía al propio tabernero; el mostrador del local retratado en el Juan José aparece forrado de zinc, un material barato que facilita tanto el aseo cuanto la recuperación de lo derramado por su superficie al servir la bebida, y no falta una manguera de goma para un servicio del agua en la cubeta que facilita una limpieza de vasos y botellas específicamente encarecida en las instrucciones escénicas de Dicenta; por tanto, si había descuido higiénico en la taberna, probablemente tuviesen que ver más en ello circunstancias de naturaleza puramente económica que justificaban la no adquisición de locales que eran tanto más higiénicos, amplios y ventilados cuanto más caros; o que explicaban el no satisfacer el pago de materiales de construcción igualmente dispendiosos como azulejos, mármoles, terrazos o revestimientos cerámicos que facilitaban la limpieza del local.

Sobre los pisos terrosos y húmedos de las tabernas asturianas, se puede leer una descripción en la novela corta de Ramón Pérez de Ayala Pilares ${ }^{36}$. Naturalmente, y aunque hasta ahora apenas si se ha aducido otro testimonio literario sobre tabernas que el de Dicenta, es obvio que, con un carácter mucho más incompleto, existen otras descripciones de la misma; en especial, las incluidas en La pata de la raposa (1912), también de Ramón Pérez de Ayala ${ }^{37}$; las de obras de Armando Palacio Valdés como La Aldea perdida (1903) ${ }^{38}$, Josée ${ }^{39}$, La alegría del Capitán Ribot ${ }^{40}$, y Santa Rogelia ${ }^{41}$; la inserta en La Regenta (1884) de Leopoldo Alas Clarin ${ }^{42}$; o los detalles proporcionados por Los vencedores de Manuel Ciges Aparicio ${ }^{43}$. Hay otros testimonios provenientes del periodismo costumbrista, por supuesto, como en el caso de «Los Chigres», de José López Dóriga ${ }^{44}$.

36 PÉRez de Ayala, Ramón: Obras Completas, Madrid, Aguilar, t. I, pp. 959-962.

37 Ibid., p. 355.

38 Palacio Valdés, Armando: La Aldea perdida, Madrid, Espasa-Calpe, 1977, pp. 79 y 199.

39 Palacio ValdÉs, Armando: Obras Completas, Madrid, Aguilar, 1959, t. I, p. 163.

40 Ibid., p. 835.

41 Ibid., p. 1683.

42 ALAS, L. (CLARÍN): op. cit.

43 Ciges Aparicio, Manuel: Los vencedores, Madrid, 1908, pp. 77-78 y 227.

44 Recopilado en Prieto, R y LóPez DóRIGA, J.: Siluetas ovetenses, Oviedo, 1889, ed. facsímil en Gijón, Auseva, 1989. 
Ahora bien, pese a que hemos convenido en darle un grado de fiabilidad estimable a esta descripción de la taberna, es necesario aceptar que aún falta por incorporarse un elemento nuevo, el consumo de la sidra en la taberna asturiana, que suponía una ritualización del acto de la bebida y una organización interna del espacio de la taberna con ostensibles diferencias con respecto a aquellos locales donde se consumía sólo, o sobre todo, vino. El detalle es tanto más importante cuanto que el consumo de sidra tenía una gran importancia, e incluso era mayor que el del vino en ciertas comarcas ${ }^{45}$.

Contra lo que pudiera pensarse de una bebida de tan acendrado tipismo, tampoco en este caso nos encontrábamos con un producto «tradicional», puesto que el verdadero momento de expansión de los plantíos de manzanos en Asturias había que situarlo a partir del siglo XVIII y a lo largo del XIX, cuando el incremento poblacional, la reactivación económica y finalmente la revolución industrial, consiguieron quebrar sus estructuras artesanales anteriores y su consumo esencialmente doméstico. La expansión de la producción sidrera se apoyó durante mucho tiempo en su mayor baratura frente al vino, y su importancia quedó reconocida en la propia denominación de la taberna asturiana.

El término de chigre con el que se conocían en Asturias estos locales, en efecto, había sido tomado en préstamo de una especie de grúa marinera para denominar a un artefacto de similar factura, armado de un largo émbolo y que, colocado en las sidrerías y tabernas del país permitía el fácil descorche de las muchas botellas que, debido a su baja concentración alcohólica, tenían que consumirse para obtener un grado estimable de euforia. Andando el tiempo, chigre pasó a denominar no ya el aparato, sino el establecimiento, y extendió su campo semántico hasta hacerse sinónimo de cualquier tipo de taberna ${ }^{46}$.

Debido a la presencia de la sidra, el espacio interno del chigre - y mucho más en el caso de la sidrería propiamente dicha o del lagar - tendía a presentar un reticulado del espacio interno mediante mesas y taburetes sensiblemente más débil. Sobre todo en los lagares, era común que los bebedores degustasen la sidra a pie firme, a la vista de los toneles del líquido, y en un lugar sin demasiados asientos debido a que el local no había sido diseñado inicialmente para ser abierto al público. Pero la imagen de los bebedores de sidra erguidos sobre el suelo, que aparece en La Pipiona y en muchos otros cuadros de género, no sólo es privativa de los lagares sino que parece haber sido en general la forma más habitual de degustación en consonancia con el peculiar modo en el que la sidra era catada.

45 Algunas cifras de consumo de sidra y vino a principios de siglo en GUEREÑA, Jean-Louis, «Una aproximación a la sociabilidad popular», op. cit., y en URíA, Jorge: «La taberna en Asturias a principios del siglo $\mathrm{XX} »$, op. cit.

46 Ver las aportaciones de PÉREZ DE CASTRO, Ramona: «Aspectos jurídicos sobre la sidra», p. 73 y ss., de JUNCEDA Avelló, Enrique: «Aspectos médicos en torno a la sidra», p. 105 y ss., y de FidAlgo SÁnCHEZ, José Antonio: «Manzana y sidra. A modo de Historia», p. 129 y ss., y «El consumo de la sidra», p. 193 y ss., en el trabajo colectivo El libro de la sidra, op. cit. 
Efectivamente, la costumbre de escanciar la bebida dejándola caer desde una botella sostenida en lo alto sobre un vaso, sujetado con la otra mano, debido a las cantidades regulares de líquido vertidas fuera del vaso y a las salpicaduras, convertía a las sidrerías en lugares especialmente húmedos, y cuyos suelos había que regar abundantemente con serrín para paliar este inconveniente. Una tertulia en una mesa en estas condiciones era un verdadero engorro, puesto que sus integrantes habrían de soportar las salpicaduras de la operación del escanciado desde los asientos, además del anegamiento de la mesa debido al continuo trasiego de los vasos y las manos goteantes sobre la mesa. Todas estas molestias, naturalmente, se atenuaban notoriamente sin el obstáculo del mobiliario.

Esta sociabilidad «a pie firme» vinculada al consumo de la sidra, en cualquier caso, parece haberse caracterizado por unos grados de intensidad mayores que los que se asociaban a la ingestión del vino. La literatura existente sobre el asunto incide con bastante frecuencia en un hecho: el de que la sidra raramente se consume en solitario, presentando su ingesta, en cambio, un fuerte carácter comunitario. La costumbre de usar para su envasado y degustación botellas y vasos de vidrio desde la instalación en 1843 de una fábrica en Gijón, tal vez no sea enteramente ajena a este fenómeno.

Desde entonces, el embotellado, escasamente usado en el siglo XVIII, permitió una conservación óptima de determinadas cualidades de la sidra, como el perfume o la fuerza del líquido que, de todos modos, se desvanecían con cierta facilidad una vez abierta ésta; por esta razón el consumo grupal y, por ende, rápido de la misma apenas daba tiempo a que se produjese este peligro. En cuanto a los vasos de sidra, tal vez su progresivo adelgazamiento hubiese facilitado su uso comunitario debido a razones de tipo económico en unos recipientes de tal fragilidad; no obstante, la extrema delgadez y diámetro de los que hoy se conocen aún no se habían generalizado antes de los años treinta y, en cualquier caso, la costumbre de que bebiese el grupo de un mismo recipiente ya existía con anterioridad; y entre los ejemplares de jarras cerámicas para la bebida de la sidra conservados del siglo XVIII y XIX no faltan ejemplos con marcas internas para señalar la dosis de cada bebedor.

De cualquier modo, el hábito de beber del mismo vaso desembocó en una complicación todavía mayor en el ya de por sí complejo ritual de la degustación de la sidra; ahora, se imponía el reservar un resto de líquido en el recipiente para, al arrojarlo por donde se habían posado los labios en el vaso, garantizar la limpieza para su siguiente usuario.

Desde otro punto de vista, la transformación de algunas costumbres del tradicional comunitarismo agrario mediante su mercantilización contribuyó también a acentuar los efectos multiplicadores de la sociabilidad tabernaria. En este sentido, la espicha, que no era en principio más que el acto de retirar el espiche de madera que sellaba un tonel de sidra, con el que el dueño de una casería obsequiaba a sus familiares o vecinos con motivo de cualquier celebración, o como pago a la ayuda comunitaria al trabajo de la tierra, desde princi- 
pios del siglo XIX se convirtió en un negocio de creciente éxito. Ahora, a cambio del pago de un derecho de entrada preestablecido, el asistente podía degustar en los lagares no sólo la sidra sino, como antaño, manjares «de lo que daba la casa» (huevos, tortilla, charcutería, empanadas o queso).

A principios del siglo XX, parece que el estándar del pago de entrada al lagar se había situado en torno a los 10 céntimos, y a ello se sumaba un canon por cada salida y posterior regreso de un exterior en el que se buscaban unos improvisados mingitorios; y es que el carácter fuertemente diurético de la sidra imponía la necesidad de salidas tanto más frecuentes cuanto mayor era el consumo del líquido. El canon por salida a principios de siglo era, como rezaban los carteles anunciadores de «a perrona la mexada» ${ }^{47}$.

Un último detalle: los testimonios escritos y las imágenes de la pintura de género son unánimes en ello; no era nada común que las mujeres tuviesen entrada en las sidrerías y lagares, que se configuraban así como lugares de una masculinidad excluyente y machista. Con la prohibición - explícita en algunos lagares - se pagaba, cierto, un tributo a los valores de la época, pero el precepto también se fortalecía por creencias como la de que los días menstruales de la mujer podían echar a perder la sidra almacenada ${ }^{48}$.

\section{DISCIPLINAS INDUSTRIALES, MEDICINA Y CRIMINOLOGÍA FRENTE A LA TABERNA}

Tal y como ha sido tratado hasta este momento el espacio interno de la taberna nos aparece como la plasmación de una lógica autónoma; como un espacio funcional que se acomoda a las pautas sociales de unos grupos que, de todos modos, aparecen sospechosamente aislados de cualquier sistema de coacciones procedentes del exterior de las clases populares. Y que la taberna sea un espacio donde es posible un notable margen de autonomía es, efectivamente, un dato que no parece razonable poner en duda; pero también lo es, y en ello habremos de detenernos un tanto, que ni siquiera en este caso es posible imaginarse un lugar para la emancipación popular al margen de los intentos del poder y del juego de coacciones y conflictos que forma parte de su contexto social. Si la categoría de sociabilidad ilumina acerca de las capacidades autoorganizativas y de la facilidad para plasmarse en los chigres las tendencias a la asociación y a la formación de grupos más o menos espontáneos, otras perspectivas pueden también clarificar su papel dentro de una lógica social más gene-

47 ARrones Peón; Luis: Hostelería del viejo Oviedo, op. cit.; JUNCEdA Avelló, Enrique: «Aspectos médicos en torno a la sidra», op. cit.; FIDALGO SÁNCHEZ, José Antonio: «Manzana y sidra» y «El consumo de la sidra», op. cit.; GONZÁLEZ FERNÁNDEZ, Eulalia: «Una historia reciente de la sidra», en El libro de la sidra, op. cit.; IBÁŃEZ DE POSADA, Esperanza: «Vasijas para el trasiego y el consumo de la sidra», Ibid.; GONZÁlEZ COBAS, M.: «El folklore de la sidra», Ibid.

48 FIDAlGo SÁNCHEZ, José Antonio: «Manzana y sidra», op. cit., p. 143. 
ral y que, globalmente, respira mucho menos autonomía. En ámbitos como el de la historiografía británica, en particular, el tema se ha desarrollado de este modo desde perspectivas que conviene recordar siquiera sea someramente. Desde la clásica aportación de E. P. Thompson acerca de la persistencia en el siglo XVIII de una cultura "plebeya» de pasatiempos, sus trabajos sobre la cultura popular tradicional han servido para certificar el vigor de estas áreas de libertad interpretadas como ejemplos de una resistencia exitosa frente a los intentos interventores del poder $^{49}$. La taberna puede verse así como una realidad inserta dentro de esta lógica, a la vez que como un espacio donde se encastillan, tal y como se ha sugerido ya, formas de ocio particularmente obsoletas o tradicionales pero que, durante un tiempo, funcionan como alternativas reales a la lógica expansiva de formas de ocio mercantilizadas. Estas últimas modalidades, ya en el siglo XVIII, comenzarán a configurarse como poderosas y manipuladoras industrias culturales; su labor de erosión de las formas tradicionales de entretenimiento se sumará así a la de los poderosos movimientos reformadores de las costumbres británicos, particularmente activos en el tránsito del siglo XVIII al XIX, y que tuvieron en la lucha contra la taberna y el consumo alcohólico uno de sus nortes esenciales ${ }^{50}$. Si lo que se busca, en fin, es identificar los principios que animan las estrategias articuladas desde el Estado o los grupos sociales hegemónicos para reconstruir las relaciones sociales que les son más favorables en un contexto armónico, la perspectiva del análisis de los mecanismos de control social se muestra como particularmente clarificadora. Una óptica, por cierto, particularmente discutida y a la que se ha motejado en ocasiones de simplificadora, al imaginarse un poder modelador de las clases hegemónicas tan absorbente, que añade intencionalidad allí donde, a veces, tan sólo funcionan las reglas impuestas por la lógica económica espontánea del mercado capitalista, o la plasmación de sencillas tácticas defensivas de corte coyuntural, sin grado alguno de construcción de su estrategia ideológica o sin intencionalidad consciente de dominación. Al final, el control social puede acabar siendo, en este sentido, una categoría reduccionista y esquemática, y a la que habría que añadir el importante defecto de imaginarse unas clases populares, en realidad, como meros actores pasivos frente a los todopoderosos agentes sociales hegemónicos que ejercen el control sobre el conjunto social ${ }^{51}$.

Con las debidas precauciones, sin embargo, la noción de control social puede iluminar el problema de la taberna y el alcoholismo desde un enfoque interesante: el de los intentos reales y conscientes, y dotados de un cuerpo disciplinar coherente e internamente estructurado, por domeñar el ocio popular; y dentro

\footnotetext{
49 Thompson, E. P.: «Patrician Society, Plebeian Culture», en Journal of Social History, $\mathrm{n}^{\circ} 4$, 1974.

so Sobre estos procesos véase la clásica aportación de PLUMB, J. H.: «La mercantilización del ocio en la Inglaterra del siglo XVIII", Historia Social, n $41,2001$.

s1 Una crítica a estos planteamientos sobre la noción de "control social», en STEDMAN JONES, G.: Lenguajes de clase, Madrid, Siglo XXI, 1983.
} 
de él, por supuesto, a la taberna. Se trataba de las coartadas académicas que intentaban justificar científicamente el ataque a la taberna y que constituían la verdadera médula de la abrumadora producción publicística de la época sobre el tema. Tres eran las vertientes principales a través de las que se articularían los tópicos de esta literatura antialcohólica. La una se localizaba en los planteamientos disciplinares sobre la fuerza de trabajo de los Ingenieros de Minas. La otra, en la medicina científica o derivados suyos como el higienismo, la medicina social que empezaba tímidamente a despuntar, o la prolongación de una muy sólida tradición de estudio de las patologías locales mediante topografías médicas. Finalmente, se abría una última e interesante vertiente a partir del desarrollo de campos como el de la sociología, la economía política o, sobre todo, la criminología, en la vanguardia de los modernos estudios de unas ciencias sociales en ciernes.

Por descontado, la construcción disciplinar de este ataque científico a la taberna no difirió gran cosa en sus argumentos esenciales dentro del conjunto de la literatura social animada por este fenómeno en los países industrializados; saltando de un país a otro los resultados de las encuestas e investigaciones a ese respecto, los tipos de argumentación, o los mismos modelos de las campañas antialcohólicas. La soltura con la que Álvaro de Albornoz discutía acerca de las campañas antialcohólicas, ligas de templanza o argumentaciones médicas usadas en áreas tan distantes como la americana o la de los países nórdicos ilustra no sólo la preocupación social de quien, al cabo, era una de las criaturas políticas más dilectas del Institucionismo del grupo de Oviedo, sino también el ascenso de un discurso antialcohólico científico de corte esencialmente transnacional ${ }^{52}$. El detalle ya exhibido en estas páginas acerca de la discusión sobre los efectos del alcohol tenida en la Academia de Medicina francesa, informa por otra parte de uno de los muchos detalles que pudieran aducirse en cuanto al tono científico de que se revistió la discusión sobre estos aspectos en el vecino país. En el Reino Unido, por lo demás, las campañas contra la taberna tuvieron un tono muy similar porque parecido era, en definitiva, el problema que había que atajar. En realidad, a partir del segundo cuarto del XIX había crecido allí el deseo de refrenar el consumo alcohólico; además de la conocida acción de las sociedades de templanza, ligas antialcohólicas o sociedades religiosas en este sentido, se había ido desarrollando una regulación estricta de la taberna y de sus actividades recreativas que hay que interpretar en este contexto. La razón última de aquel despliegue de preocupación acerca de la morbilidad, el crimen o los perniciosos efectos sociales de la taberna, sin embargo, estaba, como ya sabemos, no tanto en razones neutralmente científicas, sino en el hecho de que se proveía de espacio, calor, luz y oportunidades para el desarrollo de un amplio espectro de actividades sociales populares. Un buen conocedor del asunto, B. S. Rowntree,

52 Así se observa en su opúsculo, La instrucción, el aborro y la moralidad con respecto a las clases trabajadoras, Luarca, 1900.

Hispania, LXIII/2, núm. 214 (2003) 571-604 
había identificado ya en 1941 la verdadera causa de tan desaforado grado de construcción intelectual en torno a la taberna: «Public-houses provide facilities for people to meet for recreation and social intercourse under conditions chosen and created by thenselves» ${ }^{53}$.

No supone ninguna novedad en cualquiera de los casos el comprobar cómo constituían los ingenieros, en casi todos los ámbitos industrializados, los verdaderos especialistas y adalides de la racionalización productiva y, por tanto, de la organización del trabajo y de una mano de obra a la que había que extraer el máximo rendimiento; cuestiones todas ellas que suponían la ruptura con los ritmos irregulares de trabajo y con todo el conjunto de festividades y de pautas antropológicas que caracterizaban el ocio preindustrial. En este sentido, los ingenieros de producción británicos, los mecánicos en los Estados Unidos de Norteamérica, o los de minas en España, representaban ni más ni menos que caras distintas de una misma moneda; si bien fue perceptible muy pronto el mayor grado de perfección disciplinar que caracterizaría a los estadounidenses. Sorprende, en cualquiera de los casos, la notable sintonía del desarrollo de las reflexiones de los asturianos en el transcurso de los años 80 y 90 del siglo XIX, en relación con el momento de especial dinamismo de estas disciplinas que se vive en el resto de Europa por esta misma época ${ }^{54}$. Entre los ejemplos más destacados de este proyecto activado por los ingenieros, se encontraban, por supuesto, los trabajos de Francisco Gascue desarrollados desde principios de los 80 del siglo XIX así como, en los 90, la obra del ingeniero José Suárez. El discurso de ambos ingenieros es sumamente coincidente; puesto que, según Gascue, el obrero «industrialmente considerado» era una máquina, había que procurar extraerle el mayor efecto útil alimentándole adecuadamente - ese era «su combustible»- y procurándole todo un conjunto de ventajas que le atrajesen y fijasen al empleo industrial de acuerdo con un detallado programa paternalista en el que «la filantropía marcha de acuerdo con el interés industrial». Gascue percibía, de todos modos, que no era posible la obtención de un efecto útil adecuado sin romper con los ritmos tradicionales de trabajo propios de una sociedad agraria y sostenidos con tenacidad por un obrero mixto, a caballo entre el trabajo agrícola e industrial, y que prolongaba unos sistemas de ocio que

53 Cunningam, H.: «Leisure and culture», en Thompson, F. M. L.: The Cambridge Social History of Britain 1750-1950, Cambridge, Cambridge University Press, 1990, pp. 266 y 265. MALCOLMSON, R. W., Popular Recreations... opus cit., p. 98. La obra de ROWNTREE, B. S. (Poverty and Progress: $A$ Second Social Survey of York, Londres, Longmans, 1941) es citada por CunNINGAM, H.: op. cit., p. 316 .

${ }_{54}$ Sobre el desarrollo de las disciplinas industriales en diversos países, ver HOBSBAWM, E. J.: Trabajadores. Estudios de Historia de la clase obrera, Barcelona, Crítica, 1979, pp. 376-383; en territorio norteamericano, ver MONTGOMERY, David: El control obrero en los Estados Unidos, Madrid, Ministerio de Trabajo, 1985; sobre Asturias, ver SIERRA, José: «¿El minero borracho? Alcoholismo y disciplinas industriales en Asturias", Los Cuadernos del Norte, Oviedo, $\mathrm{n}^{\circ} 29,1985$, y El obrero soñado. Ensayo sobre el paternalismo industrial (Asturias 1860-1917), Madrid, Siglo XXI, 1990. 
suponían un alto grado de irregularidad y falta de constancia en el trabajo, así como un número alto de días de asueto consumidos en fiestas, romerías, ferias o mercados 55 .

La crítica feroz hacia estos festejos caracterizaba también la obra de José Suárez, quien les reprobaba su asociación al consumo alcohólico, las violencias que acarreaban con finales de fiesta coronados frecuentemente con peleas interparroquiales y, por supuesto, sus consecuencias en el calendario y los rendimientos laborales. La condena de la taberna tenía planteamientos muy explícitos dentro de estas coordenadas; el autor, en efecto, calificaba en 1896 como hecho que tenía forzosamente que «sorprender al espectador, que por primera vez recorre estos valles», la presencia de una cantidad «enorme, aterradora» de tabernas; verdadera "plaga», en tanto que foco «de inmoralidad y ruina de las familias" debido a la insistencia de los obreros en el «feo vicio de la bebida» o en el consumo de alimentos adulterados por los codiciosos taberneros. La taberna pasaba a ser así elemento primordial, junto con la mala alimentación y las deficiencias en el vestido, a la hora de explicar el bajo «efecto útil» de los mineros ${ }^{56}$.

De este discurso hostil contra la taberna se apropiarían también, por supuesto, una patronal frecuentemente despacienciada por el escaso éxito de las alternativas organizadas desde la empresa al ocio popular. La correspondencia del Archivo de Hullera Española, de Comillas, proporciona en parecidas fechas argumentos que, aunque sin la autoridad técnica de los sistemáticos informes de los ingenieros, son en el fondo muy parecidos. En 1895, en efecto, confesaba lo siguiente:

¿Dónde consagra el obrero mejor a Dios el día de domingo? ¿En el Círculo Obrero Católico donde recibe saludables enseñanzas para su alma y cuerpo o en esas cloacas del vicio que llamamos tabernas... donde aprende las ideas más abominables sobre todo lo que sea digno de respeto, donde se blasfema de Dios?... En la taberna se aprenden las ideas más absurdas y enloquecidas acerca del orden social, se despilfarra la salud y el dinero, pues en muchas de ellas, en habitaciones interiores, imperan otros vicios, uno de ellos el juego prohibido»s5.

La argumentación permanecería desde luego vigente bastante tiempo después de estas muestras de preocupación de los años ochenta y noventa del siglo XIX. Bien entrado ya el siglo XX, en 1911, Lucas Mallada, en un Informe sobre el estado de las minas hecho para la Dirección General de Minas y Montes,

55 GasCue, Francisco: «La industria carbonera en Asturias», Revista Minera, Madrid, 1883, pp. 372-373, 387 y ss.

56 SuÁrez, José: El problema social minero en Asturias, Oviedo, Imp. de Pardo, Gusano y Cía, 1896, p. 12. Las condenas a las romerías, ferias y, en general, el conjunto del ocio popular, en pp. $17,25,89$ y 57 .

57 La carta, de Penaves a Parent, la cita SHubert, A., Hacia la revolución. Orígenes sociales del movimiento obrero en Asturias, 1860-1934, Barcelona, Crítica, 1984,.p. 114 
clamaba contra la «vanidad» imperante que arrastraba al minero, en aquellos momentos, desde la antigua taberna hacia el siempre algo más pretencioso café. Y en cuanto a la Revista Industrial Minera, a lo largo de los años veinte, iba a publicar sucesivos artículos que volverían a incidir en la «llaga fétida y repugnante» del alcoholismo, o en la necesidad de promulgar una «ley seca», advirtiendo de paso las secuelas que podía tener la ingestión alcohólica a la hora de enconar los conflictos de clase ${ }^{58}$.

En cuanto a la medicina científica, si se limita el examen de sus argumentaciones al caso asturiano en donde han venido moviéndose esencialmente estas páginas, no parece que sus datos difieran en exceso, nuevamente, de lo que se apunta en otros lugares. Afortunadamente los puntos esenciales de esta argumentación son hoy bien conocidos. Vinculado al proceso de racionalización social burguesa y a la consolidación del orden social, el discurso antialcohólico se medicalizará desde finales del siglo XVIII y principios del XIX. Desde ese momento empiezan a publicarse observaciones sobre los efectos del alcohol en áreas como la del Reino Unido, Alemania o Francia que comienzan a ver el hábito del consumo alcohólico como una enfermedad o un problema social, aunque todavía, y sobre todo, como un problema moral. A mediados de siglo se producirán, sin embargo, importantes cambios en esta percepción. El sueco Magnus Huss, en efecto, describe en ese momento el alcoholismo crónico como un conjunto de lesiones nerviosas que se presentan en un cuadro amplio de trastornos no sólo neurológicos, sino psíquicos y de comportamiento; se podía ofrecer, de este modo, una explicación científica de un fenómeno que hasta entonces sólo se había contemplado desde un ángulo preferentemente moral, construyéndose clínicamente así la imagen del alcohólico, y asociándosele un conjunto de síntomas amplios entre los que se incluía el deterioro mental o la degeneración. La nueva mirada médica hacia el alcoholismo asociaba al fenómeno trastornos sociales como la vagancia, la indolencia, la criminalidad o la prostitución o el absentismo laboral, sosteniéndose así una noción que pivotaba sobre una peculiar tensión entre el vicio y la enfermedad. Por parecida época las teorías degeneracionistas del francés Morel, banalizaban el alcoholismo explicando su etiología a partir de la transmisión hereditaria, a diferencia de Huss, y situando a sus víctimas entre los degenerados; lo que acarreaba la miseria y el bastardeo de las poblaciones, pasando a ser así el alcoholismo un problema moral y político de primera magnitud. El determinismo biologista de Morel — de amplia difusión en España - permitía aislar así al alcoholismo de sus causas sociales haciendo del degenerativismo hereditario la causa de su miseria. En general la catarata de publicaciones, cartillas higiénicas, estudios sobre el alcoholismo o meras alusiones al asunto que se contenían en los tratados de medicina al uso en España, se inscribían en estos mimbres interpretativos; la reflexión que aquí se hacía, sin embargo, había sido tardía y de menor calado. Los

58 Ver SIERRA, José: El obrero soñado, op. cit., pp. 244-246.

Hispania, LXIII/2, núm. 214 (2003) 571-604 
médicos españoles, en general, habían hecho suyas las tesis que asociaban el alcohol a la pobreza, la degeneración física y moral, y al peligro social, sirviendo el cuadro descrito para estigmatizar a la clase obrera y justificar su miseria en causas científico-médicas. Así planteadas, las teorías acerca del alcoholismo proporcionaban la cobertura adecuada para diseñar una estrategia global de erradicación de los vicios del proletariado, colocándose los médicos en la vanguardia de la reforma social española, y presentando como algo indiscutible el achacar a causas degeneracionistas la perversión de las capas populares salvo excepciones muy contadas, como la del Dr. S. Vives, que subrayaban con razón el carácter del alcoholismo como consecuencia - y no a la inversa- de la miseria social ${ }^{59}$.

La autoridad de tales análisis no era desconocido por algunos tratadistas de la cuestión social. Fernando García Arenal, por ejemplo, en sus Datos para el estudio de la cuestión social evocaba en 1885 la perita opinión de Moleschost para describir los efectos fisiológicos de la bebida y para, en su virtud, intentar explicar la atracción ejercida sobre el proletariado ${ }^{60}$. Con todo, la propaganda antialcohólica directa tuvo uno de sus más activos apóstoles en el médico asturiano Arturo A. Buylla, hermano del conocido profesor institucionista ovetense. Su obra La lucha contra el alcobolismo (1902), un «catecismo para uso de las escuelas y talleres» del que se tiraron 10.000 ejemplares en la primera edición y que alcanzaba el mismo año una tercera de 6.000 , resumía muy bien el espíritu de las campañas antialcohólicas de estos años ${ }^{61}$. El Catecismo tuvo una buena acogida en la prensa diaria, entre las autoridades municipales de provincias como las de Oviedo, Santander y León, e incluso entre un movimiento obrero socialista que, por boca de Morato, alabó entre otras cosas «el noble empeño» que guiaba la campaña antialcohólica «plausible y humanitaria» del médico; aunque incidiendo en la necesidad de proseguir con las tareas organizativas del movimiento obrero que permitiesen rebajar la jornada y aumentar el bienestar del obrero como medio más seguro de mermar el arraigo del alcoholismo ${ }^{62}$.

En un prólogo dirigido "A los hombres de buena voluntad", la obrita, redactada al modo sintético y dialogado de los catecismos, explicaba las razones,

59 Campos Marín, R: op. cit., pp. 30-81. Como recuerda Thomas Brennan, el término de "Alcoholismo» había sido acuñado ya en el siglo XVIII encubriendo de cientifismo la condena de la taberna por las clases dirigentes, al tiempo que explicando «científicamente» la depauperación del proletariado a partir de su negligencia, indisciplina e imprevisión. Sobre el particular véase BRENNAN, T.: Public Drinking... opus cit., p. 193 y ss.

60 García AREnal, Fernando: Datos para el estudio de la cuestión social. Información becha en el Ateneo-Casino Obrero de Gijón, Gijón, Imp. del Comercio, 1885, p. 43.

61 El Carbayón, Oviedo, 12-VI-1902. Sobre la figura de Arturo A. Buylla, véase, URÍA, J.: Sociedad, ocio y cultura en Asturias (1898-1914), Oviedo, Universidad, 1991, pp. 960 y ss.; del mismo autor Una bistoria social... opus cit., p. 145; CAMPOS MARíN, R: «Lucha antialcohólica, higienismo e ideología en la obra de Arturo Buylla y Alegre», en URíA, J.: Institucionismo y reforma social en España, Madrid, Talasa, 2000.

62 MorAto, Juan José: «El alcoholismo. A D. Arturo Buylla», El Noroeste, Gijón; 27-X-1902.

Hispania, LXIII/2, núm. 214 (2003) 571-604 
escasamente relacionadas con las ciencias médicas, de la necesidad de luchar contra el alcoholismo:

«Es bien conocida la terrible influencia que sobre el organismo humano y sobre el estado moral de los individuos producen los abusos en la bebida y aun el sencillo uso de aquellas que fraudulentamente se expenden en todas partes, gracias a un industrialismo pecaminoso; nadie ignora, y todos se quejan, de lo que en la familia y la sociedad representa el alcoholismo, verdadero disolvente del hogar, y del orden en la vida de los pueblos, signo de degradación de una raza y causa de despoblación y miseria. Poner el remedio eficaz, instruyendo a la nueva generación, de la que tanto espera la pobre patria, será, pues, obra meritoria y altamente humana» 63.

Una tercera edición de otra Cartilla de higiene social. El alcobolismo y la tuberculosis $^{64}$, prolongaba en el mismo año de 1902 el activismo antialcohólico del médico; y en febrero de 1906 publicaba Buylla un periódico - la Revista Popular de Higiene- que alcanzaba en septiembre su número 14 y que, naturalmente, también combatía el alcoholismo. Significativamente, la revista aparecía no sólo con el apoyo indirecto de los anunciantes, sino también con el patrocinio directo de instituciones como el Gobierno Civil, el Casino de Oviedo, el Círculo Mercantil e Industrial, la Fábrica de Cañones de Trubia o la Sociedad Económica de Amigos del País ${ }^{65}$.

También tomaban buena nota de los perniciosos efectos del alcohol las topografías médicas desde los presupuestos de la vieja preocupación por relacionar climatología, topografía y enfermedades desarrollada en España notoriamente en el transcurso del siglo XIX. En Asturias, gracias entre otras cosas a la fundación Röel, la práctica totalidad de los concejos disponía de su topografía $^{66}$. Naturalmente, en el caso de los concejos mineros e industriales, el alcoholismo volvía a salir a flote como una plaga social. En la dedicada a San Martín del Rey Aurelio en 1922 por José María Jove, por ejemplo, se contenía una tan detallada como hostil descripción de sus locales y de las características del negocio y sus propietarios:

"Abundan estos establecimientos de modo lamentable. No hay aldea, aún la más pequeña, que no disponga de un comercio de esta índole y podría citar docenas de lugares que no pasan de treinta vecinos, donde hay dos y tres.

$\mathrm{Y}$ es que aquí poco se necesita para montar uno de estos comercios.

63 BUYlla y Alegre, Arturo: La lucha contra el alcobolismo, Oviedo, 1902, p. 5.

64 BuYlla, A.: Cartilla de bigiene social. El alcobolismo y la tuberculosis, Oviedo, La Comercial, $1902,60 \mathrm{p}$.

6s El Carbayón, Oviedo, 12-VI-1902, 2-I-1906, 17-II-1906, 3-VI-1906, y 19-IX-1906.

66 Ver RIERA, Juan: «Introducción» a la edición facsimilar de PASTOR y LÓPEZ, Pascual: Apuntes sobre la fauna asturiana (1859), Salinas, 1989, pp. 13-17.

Hispania, LXIII/2, núm. 214 (2003) 571-604 
Una mesa larga, unos barrotes perpendiculares sostén de dos tableros, un pellejo de vino blanco y otro de tinto, dos garrafones de anís y caña y una caja de botellas de cerveza, todo ello acondicionado en una habitación sucia y mal ventilada, mejor en el portal de la casa, y ya tenéis mostrador, anaquelería, género y local; ahora sólo falta al frente de todo eso un traficante de veneno dispuesto a sacar jugo a los adoradores de Baco, que no podrán faltarle, y éste surgirá enseguida en forma de viuda, inválido, vivo o vago, que son las cuatro formas de tabernero que más se dan.

La taberna [...] es el negocio más lucrativo por excelencia, no tiene quiebra, lo demuestra el hecho de que a pesar de las muchas tabernas, pocos son los comercios, aún los que parecen más incompatibles, como zapatería, estanco, albardería, etc., que no tengan su correspondiente sección dedicada a la venta de alcoholes»67.

Las disciplinas higiénicas, a su vez, debido a su ligazón estrecha con la medicina y a su peso cada vez mayor dentro de una medicina social puesta en práctica por las empresas merced a su programa de inversiones hospitalarias o a otro tipo de prácticas divulgadoras, dedicó entretanto cada vez más atención al asunto. Uno de los manuales más conocidos en este terreno en España, y que conoció varias ediciones desde 1900, el de Alfredo Opisso, era singularmente claro en la definición del alcoholismo crónico; base principal, sostenía el autor, de las locuras alcohólicas y que describía en tonos escasamente tranquilizadores:

«Esos alcohólicos suelen presentar a manera de estigmas del alcoholismo crónico ciertas perturbaciones de orden mental y corporal: carácter irritable y díscolo alternado con períodos de excesivo buen humor y alegría (bumor crapuloso o patibulario); indolencia, abandono, egoísmo, degeneración intelectual (atrofia del sentido moral, percepción escasa, lentitud en la asociación de ideas, falta de memoria reciente); reacciones convulsivas, origen de criminalidad, delirio de persecuciones, etc.

En punto a alteraciones corporales, los estigmas más importantes son: debilidad muscular, pesadillas, disminución o abolición de los reflejos tendinosos, pureza pupilar, exageraciones y disminuciones de la sensibilidad; temblor de los labios, lengua y manos; transtornos digestivos (inapetencia, mucosidades matinales, dispepsia, estreñimientos), lesiones del hígado, transtornos circulatorios (hipertrofia de corazón, degeneración grasienta del mismo, arterioesclerosis), catarros bronquiales, lesiones de riñón» 68 .

En eso consistía el cuadro detallado de los síntomas del mal, precedido de todos modos por una «forma subaguda de envenenamiento» manifestada por «accesos nocturnos durante los cuales el enfermo despierta lleno de terror, presa de alucinaciones espantosas», acompañadas además de «ideas delirantes, reacciones de defensa, fuga o agresividad». La higiene, desde luego, se estaba desarro-

67 JOVe y CANella, J. Ma .: Topografía médica del concejo de San Martín del Rey Aurelio, Madrid, Imprenta de la Ciudad Lineal, 1923, p. 59

68 OpIsso, A.: Medicina social. Estudio de las enfermedades colectivas, sus causas, profilaxis y remedios, Madrid-Barcelona, Calpe, s.f.

Hispania, LXIII/2, núm. 214 (2003) 571-604 
llando como un sistema omnipresente en los países industrializados, entre otras cosas al asociarse medidas de efecto positivo desde el punto de vista del bienestar sanitario de la mano de obra, con un bajo nivel de inversiones por parte de las empresas. La claridad del lenguaje y la facilidad de las medidas propuestas, por otra parte, hacían de la higiene un mecanismo insustituible por su accesibilidad popular en el combate contra las enfermedades más corrientes del proletariado. En su virtud, el higienismo se va decantando a lo largo del siglo XIX como una especie de compendio de los saberes sociales de carácter más pragmático en la época, lo que pudiera explicar la sintonía establecida entre esta temática y la actividad de los ingenieros de Minas o la de los arquitectos ${ }^{69}$. La precisión y el estilo didáctico brillan como notas distintivas, por ejemplo, en el estilo de manuales de Higiene industrial de tanta difusión desde principios de siglo como el de José de Eleizegui. Se apunta en su texto, por ejemplo, las causas —esta vez claramente sociales- de la «plaga social» del alcoholismo; y entre ellas, la de las necesidades de sociabilidad entre los sectores populares.

«Autores que lo han estudiado detenidamente señalan tres causas al arraigo del vicio [del alcoholismo] en la clase obrera: la disgregación de la familia; la lucha por el trabajo; la innata tendencia a la sociabilidad. La industria moderna retiene a los miembros de la familia durante todo el decurso del día, y en aquel hogar vacío congréganse sólo por las noches, viéndose obligados a hacer sus comidas en la taberna, en la cantina próxima, donde el bajo precio y la constante solicitud hace que escancie hoy vino, mañana aguardiente y adquiera en el decurso del tiempo hábitos alcohólicos. Quiere olvidar en la taberna la realidad de todos los días. ¿A un hombre - dice Leyret- que pena diez o doce horas en el esfuerzo y el sudor vamos a exigirle que hable y medite sobre historia, filosofía y literatura? ¿Qué placer puede ofrecerse [...]?

¿Cuál si no es la taberna, donde con la ayuda de algunos vasos se elevará fuera de la realidad opresiva, evadiéndose un momento de la vida de sufrimientos y privaciones que arrastra? $Y$ en su natural tendencia a la sociabilidad que se descubre en todas las clases sociales, busca en la taberna el solaz y la distracción del grupo de amigos y conocidos»

Los remedios descritos para atajar el problema, en todo caso, pasaban aquí por un programa educativo amplio asumido desde la empresa, además de por una nueva organización del ocio:

«Se impone por cuantos medios sean posibles alejar al obrero de la taberna, ya formando Ligas de templanza, ya construyendo hoteles, restaurantes, cafés, casinos, etc., que le inciten a hacer una vida distinta de la que arrastra. Las Ligas antialcohólicas inglesas suman en la actualidad cinco millones de asociados, entre los cuales se cuentan gran número de patronos y en muchas fábricas estos mismos

69 LÉONARD, Jacques: La France médicale au XIX'e siècle, Paris, Gallimard/Julliard, 1978, p. 174 y ss.; SIERRA, José: El obrero soñado, op. cit., pp. 96-97. 
establecen cafés de templanza (hace cuatro años existían 7.000), con salas de lectura, de billar, etc., y con precios ínfimos en la confección de viandas que atraen al obrero y realizan el innegable beneficio de la disminución del alcoholismo» ${ }^{70}$.

No habían sido sustancialmente distintas ni las soluciones ni la descripción de los males del alcoholismo que puede encontrarse en una obra de 1886 como las Nociones de Higiene de Nicanor Muñiz Prada, redactadas para que tuviesen aplicación entre la mano de obra minera, y que fue de texto en la Escuela de Capataces de Minas, Hornos y Máquinas de Mieres. Naturalmente, también aquí se topa con el problema del alcoholismo, al que se dedica la totalidad de la lección XIX y en donde, aparte de describirse con una minuciosidad preciosista los trastornos producidos sobre el organismo por el alcohol, se incide en sus efectos de «vicio y miseria» y el hecho de ser "para la sociedad una amenaza constante»; concluyéndose con un detallado recetario de medidas preventivas del alcoholismo que iban desde el aumento de la instrucción hasta el incremento de la represión sobre los delitos de alcoholismo, pasando por la acción estatal y municipal, la formación de sociedades de templanza, etc. ${ }^{71}$.

La taberna, convenientemente inserta en un contexto de comportamientos sociales del proletariado que se entendían como preocupantes o desestabilizadores para la armonía social, fue también - y no podía ser menos- objeto de preocupación dentro de los ambientes universitarios ovetenses, y especialmente dentro de su sector más dinámico y competente: el grupo de Oviedo de profesores institucionistas. Un grupo de profesores - no se olvide- con un proyecto de transformación del modelo político que implicaba necesariamente una intensa preocupación social, manifestada en su dedicación disciplinar en áreas verdaderamente estratégicas para la superación de las viejas estructuras de la Restauración ${ }^{72}$.

La dedicación de Adolfo Posada a la Sociología, desde la plataforma de su cátedra de Derecho Político, encaja por supuesto dentro de estos marcos. Una sociología organicista que, aunque no ignorase el conflicto social ni la compartimentación y enfrentamiento de clases, propendía hacia unos ideales claramente armonizadores. Y era esa concepción instrumental de la disciplina sociológica la que tenía que provocar las lógicas preocupaciones ante «disfunciones»

70 De Eleizegui, J.: Nociones de higiene industrial, Madrid-Barcelona, Espasa-Calpe, 1930, pp. 70-72. El manual conoce varias ediciones desde principios de siglo.

71 MUÑIZ PRADA, Nicanor: Nociones de Higiene con aplicación a los mineros de bulla. Lecciones dadas en la Escuela de Capataces de Minas, Hornos y Máquinas de Mieres por el profesor de dicha asignatura, Oviedo, 1886, pp. 122-127. Tampoco fue ajeno al asunto el sector farmacéutico; en los periódicos asturianos de la primera década de siglo aparece un reclamo del poco menos que milagroso Polvo Coza, de la Coza Powder Company, que anunciaba la curación del borracho «aún contra su voluntad», y del que se advertía "que la mujer, hermana o hija del bebedor, le pueden administrar sin saberlo él y sin que se necesite decirle lo que determinó su cura». Véanse ejemplos del anuncio en $E l$ Carbayón, Oviedo, 20-X-1908 y 23-X-1910.

72 URía, Jorge: "Clarín y el grupo de Oviedo», en Clarín y su tiempo. Exposición conmemorativa del centenario de la muerte de Leopoldo Alas (1901-2001), Oviedo, Cajastur, 2001, pp. 89-101. 
sociales que, como las enfermedades, interferían lo que se entendía que era el normal y equilibrado discurrir de la sociedad. Nada más lógico por tanto que el espectáculo de un anarquista de la propaganda por el hecho hiciese perder la calma a Posada, calificándolo casi en términos patológicos de «desgraciado criminal» "ciego por la vanidad», aquejado de un «orgullo insano» que fortalecía un carácter de «fanático semiignorante, pseudo-ilustrado». Y nada más lógico por consiguiente, que el alcoholismo y la taberna se anatemizasen como un «verdadero abismo sin fondo hacia donde rueda la mayor parte de los nuevos rendimientos que obtiene el trabajador de la mina, del taller y del campo» ${ }^{73}$.

La preocupación social era también otra de las constantes dentro de la actividad intelectual de Adolfo Buylla, de cuya docencia de Economía Política su amigo Posada diría que era «una cátedra de verdadera economía social». Buylla, naturalmente, también consideraría negativamente el problema del alcoholismo, y las instituciones y sociedades que se habían creado a nivel internacional para combatirlo serían para el profesor, dentro de un amplio conjunto de otras medidas legislativas, «victorias alcanzadas en la lucha contra los males sociales» ${ }^{74}$.

Andando el tiempo, uno de sus discípulos más aventajados, luego una de las figuras más conocidas del radicalismo republicano, Álvaro de Albornoz, emprendería su vida pública con un trabajo al que ya se ha aludido con anterioridad, La instrucción, el aborro y la moralidad con respecto a las clases trabajadoras, donde se contenían datos muy precisos y encomiásticos sobre los movimientos antialcohólicos en Europa o América, y en donde, por supuesto, tampoco faltaba la condena de «la taberna, iaquella atmósfera impura cargada de vapores alcohólicos en que flotan la miseria y el crimen, secuela inevitable de la embriaguez que degrada al hombre hasta rebajarle al nivel de la bestia! ${ }^{75}$.

Pero no hay duda de que el campo disciplinar que más y mejor iba a tocar el tema del alcoholismo erá el de la criminología. Una disciplina, por cierto, en donde el catedrático ovetense Félix de Aramburu parece haber brillado con mayor luz de la que sugiere su no muy abultada obra, o el silencio con que los historiadores del Derecho español lo tratan. La clave de ello tal vez esté en la predilección del catedrático por la conferencia o la enseñanza como alternativa de difusión intelectual.

Con todo, la publicación en 1887 de La nueva ciencia penal señalaría uno de los hitos en España de la difusión de las teorías lombrosianas de la escuela antropológica o positiva, siquiera fuese para combatir el determinismo inherente

73 POSADA, Adolfo: Prólogo a CANALS, Salvador: Asturias. Información sobre su presente estado moral y material, Madrid, 1900, p. XXXII. Sobre la obra de Posada véase LAPORTA, F. J.: Adolfo Posada: Política y sociología en la crisis del liberalismo española, Madrid, 1974; sobre su idea de conflicto social, URIA, J.: «Posada, el Grupo de Oviedo y la percepción del conflicto social», en URÍA, J.: Institucionismo..., opus cit.

74 BUYLLA, Adolfo A.: La protección del obrero, Madrid, 1910, p. 14.

75 AlBORNOZ, Álvaro de: La instrucción, el aborro y la moralidad con respecito a las clases trabajadoras, Luarca, 1900, pp. 19-20.

Hispania, LXIII/2, núm. 214 (2003) 571-604 
a las tesis de la predeterminación hacia el delito de determinados tipos antropológicamente definidos. El caso es que en la transición del siglo XIX al XX, y aunque algo enfriada la admiración por los planteamientos lombrosianos, el entusiasmo criminológico seguía aumentándose con nuevos ingredientes, y los alumnos universitarios continuaban visitando la cárcel de la ciudad para medir con ahínco cráneos y extraer las pertinentes conclusiones de sus tendencias penales. Aramburu, naturalmente, también condenó la «degradación orgánica» de la embriaguez, que asociaba a todo un conjunto de comportamientos delictivos ${ }^{76}$.

Cuando Aramburu se fue a Madrid, llamado por Salillas para participar como profesor de la flamante Escuela de Criminología, el relevo fue tomado por el catedrático Enrique de Benito, quien pronto montaría su Museo y Laboratorio de Criminología, y que no tardaría mucho tiempo en dejar clara su condenación de la taberna en tanto que causa primordial de la criminalidad, junto con la abundancia y facilidad de uso de las armas, y la mayor impunidad de los delincuentes desde la imposición del juicio por jurados ${ }^{77}$.

Pero sería la aparición en 1900 de la clásica y documentadísima monografía de Manuel Gimeno y Azcárate sobre La criminalidad en Asturias, la que cargaría más las tintas sobre el alcoholismo como causa de la criminalidad regional, proporcionando datos objetivos con los que iba a alimentarse buena parte de la propaganda antialcohólica. El alcoholismo, esta vez, «figura en primero y especial lugar» entre «los factores que mayor contingente dan a la criminalidad", describiéndose la taberna en un conocido texto, que la pinta como un espacio «que ofende y predispone al delito», en donde «las blasfemias, las injurias, las interjecciones brutales flotan azotando el rostro, $[\mathrm{y}]$ la voluntad se enardece», y en el que «cada mirada es un reto, la palabra un ataque» y la permanencia en el local «un albur de vida o muerte» ${ }^{78}$. Por supuesto la asociación entre los delitos y su ubicación en las proximidades de las tabernas, es algo que se documenta fehacientemente en la obra de este autor; pero ello no demuestra en absoluto relaciones directas de causa efecto entre una cosa y la otra. En primer lugar, porque la taberna era un espacio central en buena parte del ocio popular y, por tanto, era más fácil que tuviese lugar allí que en otra parte tanto las desgracias cuanto buena parte de las venturas del proletariado. Además, y como ha resaltado Thomas Brennan, la violencia funcionaba entre las capas populares como un modelo antropológico de solución catárquica para las rivalidades de estatus, prestigio u «honor»; si eso era así, la taberna volvía a ser un lugar lógico para su desarrollo, sin que el consumo alcohólico tuviese que intervenir en ello gran cosa.

Pero con ser los textos de Gimeno de Azcárate un acabado ejemplo del tipo de análisis criminológico de la taberna sus tesis de fondo, por supuesto, eran

\footnotetext{
76 ARAmburu, Félix de: Monografía de Asturias, Oviedo, 1899, pp. 228-230 y 327.

77 BENITO, Enrique de: «El crecimiento de la criminalidad en Asturias», El Noroeste, Gijón, 19I-1907.

78 Gimeno de AzCÁRATE, Manuel: La criminalidad en Asturias, op. cit., pp. 52-53.
} 
compartidas por muchos otros autores. Constancio Bernaldo de Quirós, en una de sus más celebradas obras, había asociado de modo diáfano la mala vida, con el alcohol y las tabernas:

«La mala vida es alcohólica, y el alcoholismo en ella es a la vez causa, síntoma y consecuencia, todo enredado tan inextricablemente, que sólo procediendo caso por caso sería posible desenredarlo. [...].

El cuadro de la noche alcohólica en la población es característico. A una hora determinada, todo el elemento trasnochador se halla en disposición de beber, porque en todos los lugares abiertos hay despacho de bebidas que se consumen con mayor o menor desenfado. Curiosas son, v. gr., las adaptaciones al medio de los alcoholistas en los cafés concurridos: el llamado té frío — vino jerez-, el servicio invertido de los líquidos (el aguardiente en la copa del agua y el agua en la del aguardiente, etc., etc.).

Entonces es cuando, a la hora de los placeres viciosos de la sociedad, debe estudiarse el alcoholismo en la mala vida, descendiendo a las tabernas miserables y a los cafetines de ínfimo orden, donde gozan embriagándose los malhechores»79.

Caben pocas dudas acerca de la voluntad conscientemente interventora de todos estos autores en cuanto a los patrones de conducta social. Sería un error, sin embargo, darle a todos estos intentos de control social más alcance del que realmente llegaron a tener. Pese a las condenas casi unánimes acumuladas sobre la taberna y dentro de las cuales se contaban las de un movimiento socialista que también pretendía expulsar al proletariado de la taberna y atraerlo hacia la Casa del Pueblo, lo cierto es que se continuó acudiendo imperturbablemente a la cita cotidiana con la taberna. Todas las tentativas para impedirlo fracasaron; y cuando se acometió la más seria, el intento de cierre un día a la semana coincidiendo con el descanso dominical, implantado desde 1904, los taberneros respondieron cambiando la inscripción de su negocio por el de «cafés económicos» para burlar una ley en la que los cafés burgueses figuraban entre las excepciones de su cumplimiento, y movilizándose en torno a gremios que consiguieron afrontar con éxito esta amenaza ${ }^{80}$.

Pero ni el escamoteo de la ley ni la resistencia activa hubiesen sido posibles sin una paralela presión de la demanda popular de sus usuarios, toda vez que la

\footnotetext{
79 Bernaldo de Quirós, C. y Llamas Aguilaniedo, J. Mª . La mala vida en Madrid. Estudio psicosociológico con dibujos y fotografías del natural. Zaragoza, Egido, 1997 ( $1^{\text {a }}$ ed. en Madrid, B. Rodríguez Serra, 1901), p. 94.

80 A principios del siglo XX, Álvaro de Albornoz comentaba los beneficiosos efectos de la ley de 1856 prohibiendo la venta de alcohol los días festivos, aunque más tarde se hubiese acotado tan sólo el horario de apertura, así como la de 1871, que establecía una limitación en la cantidad de tabernas por número de habitantes (vid. ALBORNOZ, A.: La instrucción, el aborro y la moralidad, op. cit., pp. 72-73). La ley de 1871 también era comentada en parecidos términos por Rafael Fuertes Arias (Fuertes ARIAS, Rafael: Asturias industrial. Estudio descriptivo del estado actual de la industria asturiana en todas sus manifestaciones, Gijón, 1902, p. 135.
} 
coacción sobre las tabernas llegó a ser bastante fuerte. Todavía en 1908, en Avilés, fueron arrestados la totalidad de los taberneros por haber abierto sus locales en domingo, habiendo de habilitarse como cárcel improvisada la Escuela de Artes y Oficios; en 1910, en Gijón, fueron multados con 40 pesetas los 34 que infringieron la prohibición, y la prensa de estos años está llena de referencias a los escarceos entre la ley y los propietarios de tabernas. El fuerte sentido corporativo de estos negociantes, en todo caso, fue antecedente de su cristalización en verdaderas sociedades de resistencia de «vendedores de bebidas al por menor", en los núcleos urbanos de Oviedo y Gijón, después de que la Guerra Mundial incrementase los precios de los alcoholes y de que, sobre todo en el transcurso de los años 20 , se produjese una movilización creciente de las "clases medias» entre las que, sin duda, había que contarles a ellos.

Tampoco parecen haber tenido éxito los intentos de formar sociedades de combate contra el alcohol; funcionó, desde luego, una Sociedad de Templanza en el siglo XIX bajo el paraguas protector de la poderosa empresa de Duro y Cía.; pero hasta 1927, fecha en la que aparece en Mieres la Sociedad de Abstinencia Alcohólica, no consta la existencia de nada parecido. Es cierto que la moralidad obrera penalizaba la pertenencia a sus sociedades de socorros, cooperativas, etc. a los borrachos; pero esta era una defensa normal contra socios gravosos que podían, por ejemplo, echar a perder el sistema de prestaciones de socorros o, simplemente llevar por los cerros de Úbeda sus reuniones y vida asociativa.

Con todo, y pese a que con frecuencia se ha incidido aquí en la capacidad de la taberna para sobreponerse a las amenazas que le llegaban de un exterior frecuentemente hostil, no debe por ello pensarse en la taberna como en un espacio de sociabilidad popular químicamente puro y con capacidad para sostener una evolución autónoma de las pautas de conducta social. Si es que la taberna era un lugar indispensable en la trama del ocio popular, es muy cierto a la vez que ese ocio estaba cambiando también en la taberna. El suyo era tanto un espacio de parapetamiento y resistencia del ocio de las clases populares frente a los embates de su exterior, cuanto una caja de resonancia de las variaciones que se registraban en el conjunto social del que, fatalmente, no podía mantenerse al margen. 